\title{
International Asset Pricing, Currency Risk and Integration of Markets
}

\author{
Sema BAYRAKTAR *
}

\begin{abstract}
This study attempts to test the conditional version of the international asset-pricing model proposed in Bayraktar $(2000,2009)$ by using a parsimonious multivariate GARCH process. The theoretical model, contrary to previous empirical studies that have used random selection of currency risks, determines which currencies should be included in an empirical test, thus avoids this kind of random selection bias. The results from both full and sub-samples regressions provide some weak evidence for the existence of exchange rate risks, thus partially support the theory. However, exchange rate risks' premia are found considerably smaller than that of market risk.
\end{abstract}

Keywords: Market integration, Market segmentation, Exchange rate risk, Asset pricing, GARCH

JEL Code Classification: G150, F31

\footnotetext{
* Assistant Prof. Dr. School of Advanced Vocational Studies, İstanbul Bilgi University , Turkey, e-mail: sbtur@bilgi.edu.tr

Copyright $\odot$, 2014 International Ataturk Alatoo University.
} 


\section{Introduction and Literature Review}

Many theoretical papers have analyzed the effect of exchange rate risk on international asset pricing. These studies in the literature either have concluded that exchange rate is irrelevant or it can be hedged or were unable to obtain meaningful closed-form pricing models with exchange rate. (Garuer Frederick,L.A., Litzenberger Robert H. , \& Stehle Richard E. , 1976) derives closed-form asset pricing equations in a multi-good and two-period environment. They show that, when purchasing power parity (PPP) holds and all investors have identical consumption tastes, the asset prices depend on the payoff from the asset and on the marginal utility of aggregate world real wealth and asset payoff. They also analyze the case where commodity trade restrictions exist and find out that in this case optimal portfolios are different for investors from different countries. However, they conclude that this is because of the different relative prices but not because of the different numeraire currencies that investors face. Thus, what matters in asset pricing according to (Garuer Frederick,L.A., Litzenberger Robert H. , \& Stehle Richard E. , 1976) is not the exchange rate but the relative price of the commodities. (Eugene \& Andre,F. , September 1979) and (Adler \& Dumas, 1983) also support (Garuer Frederick,L.A., Litzenberger Robert H. , \& Stehle Richard E. , 1976)

On the other hand, in (Solnik Bruno, 1974a) the inflation is zero and deviations from PPP are due to the investors' different consumption tastes. Solnik defines this exchange risk due to the PPP deviations as the "real exchange risk". He assumes that covered interest rate parity holds, thus exchange rate can be hedged by borrowing in the relevant country. For the case where the stock market risk is independent from exchange risk he finds that a three-fund separation theorem holds. According to this theorem every investor would hold a combination of "a portfolio of all stocks hedged against exchange risk (the world market portfolio), a portfolio of bonds, speculative in the exchange risk dimension and the risk free asset of their residence country". (Solnik Bruno, 1973)also investigates the more general case where the stock market risk is not independent of exchange rate risk. In that case investors hold a combination of four funds. More importantly, stock investments cannot be hedged perfectly against exchange risk any more.

Solnik's theory can be traced back to an older study by (Heckerman Donald, 1972). Heckerman in a two-country two-good model examines the effects of exchange rate on the optimal portfolio selection. He creates a wealth function, which decreases by the increase in relative price of consumption goods (since the good prices can be assumed to be equal to one, the relative price is also the exchange rate). He shows that the consumption pattern of an investor is a very important factor in determining the optimal portfolio. As long as the investor consumes imported goods he/she cannot ignore the changes in the relative price of consumption goods and would hedge the relative price uncertainty by purchasing the asset denominated in foreign currency (foreign risk-free bond in this study). 
Heckerman's model unfortunately does not include risky securities, thus falls short of showing the effects of exchange rate on risky security pricing.

On the other hand, most empirical studies on international asset pricing models have simply extended the classic version of the CAPM to an international framework, thus omitting the currency risk as an additional pricing factor. These models basically used a world market risk instead of national market risk to model asset pricing in international context. Some of these studies (Korajczyk \& Viallet, C., 1989;Solnik Bruno, 1974a; Stehle, 1977) were based on the unconditional version of the international asset-pricing model. Thus they were also ignoring the conditioning information that becomes periodically available to investors. Most of the other studies (Harvey C. , 1991) and (Bekaert \& Harvey,C., 1995) which filled this gap by testing a conditional version of international CAPM still neglected the exchange rate risk. Only starting with (Solnik Bruno \& Dumas, B., 1995) and (Santis \& Gerard, B., 1998), the conditional version of international asset pricing where exchange rate risk is incorporated as an additional pricing factor has been analyzed. These two studies provided evidence for the existence of currency risk premia. (Santis \& Gerard, B., 1998) also showed that a model where both the risks and risks' prices vary through time should be used to detect the presence of market risk or exchange rate risk. Later, many studies like (Cappiello, Castrén , \& Jääskelä, 2003), (Chang, Errunza, Hogan, \& Hung, 2005), (Hsing, 2011), (Naik \& Padhi, 2012) etc. have shown the importance of exchange rate risk in conditional international asset pricing.

This study also attempts to test the conditional version of the international assetpricing model proposed in (Bayraktar, 2009; Bayraktar, 2000) by using a parsimonious multivariate GARCH process. Time varying characteristic of the risks are analyzed by testing the model on both full-sample and sub-samples basis. To pin down the points of structural breaks (where the parameters' structure changes), the procedures known as the Cusum Squares Test, Quandt's Loglikelihood Ratio Test (Quandt, 1958; Quandt, 1960), and the Chow Test (Brown, Durbin, J., \& Evans, J.M., 1975; Harvey A.,1990) are utilized. These procedures confirm that parameters are not constant over time. Thus, the results are consistent with the findings of (Santis \& Gerard, B., 1998)also predicting time varying risk prices.

(Solnik Bruno \& Dumas, B., 1995) and (Santis \& Gerard, B., 1998), when they have analyzed the conditional version of international asset pricing with exchange rate risk as an additional pricing factor, they both have determined sources of exchange risk premium depending on the dominancy of the currencies in the world portfolio. Thus, they have selected the Deutsche mark, the Japanese yen, and the British pound as the three sources of exchange rate risk. However, the authors themselves accept that selection of exchange rate risks in this way can introduce a potential bias in the estimation of the currency risk. The present study circumvents this problem, since the model proposed by Bayraktar leads the way to determine which 
currencies should be included in an empirical test. Along with the lines of the theory, in the empirical tests of each country the real exchange risks of this particular country's leading trading partners should be included. This is the main contribution of the study to the literature. The results from both full and subsamples regressions provide some weak evidence for the existence of exchange rate risks, thus they are consistent with the previous studies. In addition, exchange rate risks' premia are found considerably smaller than that of market risk.

The fact that exchange rate is important is asset pricing would have important implications for the international asset pricing theory. First of all, it would put into question the validity of classic asset pricing models that generally take the world market index as the only explanatory variable. Second, the model used here is a candidate to explain one probable channel between asset prices and exchange rates. Since the consumers prefer to comsume foreign goods and/or invest in foreign securities they need to hold foreign currency too. This need provides a linkage between exchange rate risk and asset pricing which could open a way to explain the spillover effect of financial market crises. Finally, since the model tested under segmented and integrated markets, it may provide some clarification in terms of whether one of these market structures has superiority over the other in terms of the stability of the market. Naturally, more researches are needed to reach this final conclusion.

The structure of this study is as follows. The next section provides the return relations that are going to be tested. Third section presents the data and its simple statistics. The methodology used to test the relations is explained in section four. Section five explains how the structural breaks are determined; this section can be skipped without losing the integrity of the article. Sixth section examines the preliminary results. Final section concludes the paper.

\section{Methodology}

Bayraktar (2000 and 2009) provide a theoretical model to examine the impact of exchange rate risk under various forms of market segmentation/integration; namely segmented, mildly segmented and integrated. For that purpose, in a meanvariance framework, a two-country, two-period, two-goods model is analyzed assuming that Purchasing Power Parity holds ${ }^{1}$. She proposes that exchange risk resulting from uncertain inflation (inflationary exchange rate risk) is one of the important determinants of real equity prices even when markets are integrated. To test the model with exchange rate, first, the equations that defining security prices

\footnotetext{
${ }^{1}$ Since PPP is assumed to hold, exchange rate risk is pure monetary one, resulting from commodity price changes. In other words it is not the real exchange rate risk. Real exchange risk due to deviations from the purchasing power parity (PPP) is more meaningful but author asserts that it makes the model analytically unsolvable.
} 
are converted to the ones defining returns ${ }^{2}$. Unfortunately, since mildly segmented model is a very complicated one; empirical evidence is statistically analyzed only for the models of integrated market and segmented market structures. In the integrated market the following relation gives real return of the security:

$$
R_{i t}=b_{0}+b_{1 i} E\left(1 / I_{t}^{i}\right)+b_{2 i} \operatorname{Cov}\left(1 / I_{t}^{i}, R_{M}\right)+b_{3} \operatorname{Cov}\left(R_{i t}, R_{M t}\right)+\varepsilon_{i t}
$$

where $R_{i}$ is real return of the security, $l^{i}$ is a specially designed consumption-based inflation index of country $i, R_{M}$ is real return of market portfolio. The theory predicts the following restrictions related to the parameters;

$b_{0}=0, b_{1 i}>0, b_{2 i}<0$, and $b_{3}>0$.

Thus, the equation above tells us that the return of a security in integrated markets is positively correlated to 1 ) the expected value of inverse of inflation index and to 2) its covariance with market portfolio, and negatively correlated to the 3 ) covariance of market return with inverse of inflation index. The second (expected value of inverse of inflation index) and third variable (covariance of market return with inverse of inflation index) are the additional variables to the classic CAPM. They are going to be called as "exchange rate risks" from now on since consumption based inflation indexes not only includes the prices of home products but also those of foreign products consumed by the specific country ${ }^{3}$. Thus inflationary exchange rates affect the real purchasing power of consumers.

The theory also predicts that the prices of each source of exchange rate risks differ for each country, while the price of market risk is common across all countries.

In segmented market, the real return of the security is defined as follows:

$$
\begin{aligned}
& R_{i t}=b_{0 i}+b_{1 i} \vartheta^{2}\left(R_{i t}\right)+b_{2 i} \operatorname{Cov}\left(1 / I_{t}^{i}, R_{i t}\right)+b_{3 i} \operatorname{Cov}^{2}\left(1 / I_{t}^{i}, R_{i t}\right)+ \\
& b_{4 i} \operatorname{Cov}\left(1 / I_{t}^{j}, R_{i t}\right)+b_{5 i} \operatorname{Cov}{ }^{2}\left(1 / I_{t}^{j}, R_{i t}\right)+b_{6 i} \operatorname{Cov}\left(1 / I_{t}^{j}, R_{i t}\right) \operatorname{Cov}\left(1 / I_{t}^{i}, R_{i t}\right)
\end{aligned}
$$

where $l^{j}$ is the inflation index of country $j$. In a simplified two-country model, it is the inflation index of foreign country. In real data, that is a multi-country environment, it is assumed to be as the weighted inflation index of the leading exporting countries to the particular country $i$ whose national equity index is the dependent variable of the regression.

This relation above shows us that the security return in segmented market is related to its 1) variance, 2) covariance with inverse of its own inflation index, and 3) covariance with a weighted inflation index of its leading exporting countries.

\footnotetext{
${ }^{2}$ The return equations are a little bit different from the ones given in Bayraktar (2009). Here I use the equations without having the risk-free rate. These equations can be obtained from the author or unpublished dissertation by Bayraktar (2000).

${ }^{3}$ For the complete definition and derivation of inflation indices, please see Bayraktar (2000).
} 
These last two terms also enter to the formula in their second moments and as an interaction term. In segmented market case, all variables except the variance of the return are related to uncertainty of the inflationary exchange rate risk. The theory also predicts the following restrictions related to the parameters;

$b_{0 i}>0, b_{1 i}>0, b_{3 i}>0$ and $b_{4 i}>0$.

The signs of the other variables are ambiguous.

As explained in (Bayraktar, 2000), as long as investors are consuming the imported goods, in the absence of risk-free asset, inflationary exchange rate risk is one of the important determinants of real equity prices even when markets are integrated. This is the case because the exchange rate risk, through consumption-based price indices, affects the real purchasing power of consumers even if the Purchasing Power Parity (PPP) holds. Thus, the specifically designed inflation indices in both models for the integrated and segmented market cases show us how important are the trading relations in pricing assets. The main contribution of the models therefore is the fact that, contrary to the previous researches, it provides us which exchange rates should be added to the regression of pricing assets. Accordingly, regression to be set up would be specific for each country since the exchange rates would be those of countries which are the leading exporting countries to that country. As explained in the literature section, (Solnik Bruno \& Dumas, B.,1995) and (Santis \& Gerard, B., 1998)both have determined sources of exchange risk premium depending on the dominancy of the currencies in the world portfolio. This type of selection of exchange rates may introduce a bias to the model, already accepted by the authors. Since the models provide a way to determine which currencies should be included in the empirical asset pricing tests, the present study avoids this problem. This is the main contribution of the study.

For the estimation of security return relations, a conditional version of international asset pricing model is used. In literature, $\operatorname{GARCH}(1,1)$ processes have been popularly used to estimate the conditional versions of asset pricing4,5 (Ashley \& R.\&M. Patterson D., 2010; Bollerslev, 1990; Bollerslev\&M.Wooldridge, J., 1992; Hansen\&Lunde A., 2005).

With $\operatorname{GARCH}(1,1)$ parameterization, the equations systems that are going to be tested in integrated market would be formalized as follows:

\footnotetext{
${ }^{4}$ Since the autocorrelations of the stock returns are not predominantly significant, the analysis does not need to be corrected for spurious autocorrelation in the market indices. On the other hand, in most cases, significant autocorrelation is detected in short lags for the squared returns. This implies that a GARCH parameterization for the second moments would be appropriate for the stock returns.

${ }^{5}$ The selection of the process $\operatorname{GARCH}(1,1)$ is also due to the computational difficulties. Since there are many independent variables in the models, it may be impossible to estimate the parameters at higher level GARCH models.
} 


$$
\begin{aligned}
& R_{i t}=b_{0}+b_{1 i} E\left(1 / I_{t}^{i}\right)+b_{2 i} \operatorname{Cov}\left(1 / I_{t}^{i}, R_{M}\right)+b_{3} \operatorname{Cov}\left(R_{i t}, R_{M t}\right)+\varepsilon_{i t} \\
& \mathcal{E} \sim N\left(0, H_{t}\right) \\
& H_{t}=C^{\prime} C+A^{\prime} \varepsilon_{t-1} \varepsilon_{t-1}^{\prime} A+B^{\prime} H_{t-1} B
\end{aligned}
$$

where $C$ is a $(N \times N)$ symmetric matrix and $A$ and $B$ are $(N \times N)$ matrices of constant coefficients and $N$ is number of risky securities. The system in segmented market would be formalized similarly. The representation of the first term in the second equation of the system guarantees $H_{t}$ to be positive definite. The full parameterization of this system necessitates the estimation of $(2 x N x N)+N(N+1) / 2$ parameters, where $N$ is the number of variables. To make the estimation achievable, often, either correlations are restricted to be constant (Bollerslev,1990)or A\&B are restricted to be diagonal matrices (Bollerslev, Engle, R.F., \& Wooldridge, J.M.,1988). The diagonal matrix parameterization implies that the variances in $H_{t}$ depend only on past squared residuals and an autoregressive component, while the covariances depend upon past cross-products of residuals and an autoregressive component. If cross-market dependencies exist, as documented by (Hamao, Masulis, R.W. , \& Ng., V., 1990) and (Chan, Karolyi, G.A., \& Stulz, R.M., 1992) when high frequency data used, then this diagonal parameterization may be quite restrictive.

To test the return relations, a full parameterization of $\operatorname{GARCH}(1,1)$ process is implemented in this study. To make the analysis numerically tractable, the parameters are estimated for each security return separately. This implies, for the model tested here, using of a trivariate $\operatorname{GARCH}(1,1)$ process in both integrated and segmented market cases. In integrated market case, the risky securities are world market return, national index return and inverse of national inflation index, thus $N$ is equal to three. In segmented market case, risky securities are national index returns, inverse of national inflation index, and inverse of foreign inflation index, thus $N$ is still equal to three. Moreover, a two-stage estimation methodology is applied to estimate the parameters rather than estimating a simultaneous system. First, time varying risk measures using $\operatorname{GARCH}(1,1)$ representation are generated; next these generated time-varying risk measures are used as explanatory variables in simple regressions for the relevant particular stock return. Pagan (1984) examines the consistency and asymptotic distribution of using this two-stage approach and reports that as long as the first stage produces consistent estimates of time varying risks, the second stage will also produce consistent estimates.

The first-stage estimation is implemented by using maximum likelihood estimation techniques. Under the assumption of conditional normality, the log-likelihood function can be written as follows: 
$\ln L(\theta)=-\frac{T N}{2} \ln 2 \pi-\frac{1}{2} \sum_{t=1}^{T} \ln \left|H_{t}(\theta)\right|-\frac{1}{2} \sum_{t=1}^{T} \varepsilon_{t}(\theta)^{\prime} H_{t}(\theta)^{-1} \varepsilon_{t}(\theta)$

where $\theta$ is the vector of unknown parameters in the model. However, since it was already mentioned in previous section that normality assumption is violated in the sample, which is often the case in financial time series, the quasi-maximum likelihood (QML) approach proposed by (Bollerslev \& M.Wooldridge,J.,1992)is used to estimate the model. The QML estimator is consistent and asymptotically normal under fairly weak conditions. Non-linear optimization is performed by using Broyden, Fletcher, Goldfard, and Shanno (BFGS) algorithm.

$s_{r}=\left(\sum_{j=k+1}^{r} w_{j}^{2}\right) /\left(\sum_{j=k+1}^{T} w_{j}^{2}\right)$

In the second stage, first the constancy of the regression parameters over time $E\left(s_{r}\right) \pm c_{0}$

(model stability) is examined by utilizing the cusum squares tests, Quandt's loglikelihood test, and the Chow test. Cusum squares test developed by (Brown, Durbin, J., \& Evans, J.M., 1975)is an appropriate test for time-series data especially when one is not sure when a structural change might have occurred in time. The null hypothesis is that the coefficient vector is the same in every period; the alternative is that it (or the disturbance variance) is not. This test uses squares of recursive residuals, $w_{r}^{2}$, and is based on the plot of the quantities against $r$ for $r=k+1, \ldots \ldots . . T$ where $k$ is the number of explanatory variables in the regression model, and $T$ is the total number of observations. $s_{r}$ is the ratio of sum of squared recursive residuals up to time $r$ to the sum of squared recursive residuals over the whole period. Under the null, $s_{r}$ may be shown to have a beta distribution with mean of $(t-$ $k) /(T-k)$. This suggests drawing a pair of lines

parallel to the mean value line, $E\left(s_{r}\right)$, and rejecting the null hypothesis if either of the lines is crossed. $c_{0}$ depends on both $(T-K)$ and the significance level desired. Tables may be found in (Harvey A. , 1990)and (Johnston, 1984).

As a complement to the cusum squares test, Quandt's log-likelihood ratio technique, described in two papers by (Quandt,1958; Quandt,1960), is employed. The null hypothesis is that the observations in the time segments $(1, \ldots r)$ and $(1+r, \ldots . . T)$ come from the same regression; the alternative is that they come from two different regressions. The Quandt's log-likelihood ratio can be calculated as

$\lambda_{r}=\frac{1}{2} r \log \sigma_{1}^{2}+\frac{1}{2}(T-r) \log \sigma_{2}^{2}-\frac{1}{2} T \log \sigma^{2}$

where $\sigma_{1}{ }^{2}, \sigma_{2}{ }^{2}$ and $\sigma^{2}$ are the ratios of the residual sums of squares to number of observations when the regression is fitted to the first $r$ observations, the remaining $T-r$ observations and the entire set of $T$ observations, respectively. The estimate of 
the point at which the structural change occurred is the value of $r$ at which $\lambda_{r}$ attains its minimum. Since the distribution of $\lambda_{r}$ under the null hypothesis is not known, there is not a test developed for its minimum. However, Quandt's log likelihood ratio is just used as a complement to Cusum Squares test. Moreover, once the structural breaks points are estimated by these two methods, Chow test can be applied to re-test the existence of structural change in the regression parameters at these estimated break points. Chow test is a more powerful test than the Cusum Squares test. However, it is a specific test in the sense that one has to know at which point the structural break occurred to implement that test. The Chow test statistics has an F-distribution and is given by

$$
F(k, T-2 k)=\frac{\left[S S E_{T}-\left(S S E_{1}+S S E_{2}\right)\right\rfloor / k}{\left(S S E_{1}+S S E_{2}\right) /(T-2 k)}
$$

where $S S E_{1}, S S E_{2}$, and $S S E_{\mathrm{T}}$ are the residual sums of squares from the regression on the first $r$ observations, the remaining $T-r$ observations, and the entire $T$ observations respectively. The null hypothesis is that there is no structural change at $r$.

Once the structural change points in time are determined for each G7 country, as the next step in the second stage, security return relations for both integrated and segmented market cases are estimated by implementing simple regressions for both full period and sub-periods. In these regressions, t-statistics are calculated by using the procedures suggested by (Newey, W.K. \& Kenneth,D.W., 1987) for correction of the heteroskedacticity related to the dependent variables. Finally, two models, integrated market model and segmented market model, are compared in terms of their explanatory power for security returns. Since the models are not nested, J-test proposed by (Davidson \& MacKinnon, J., 1981)is used for that purpose.

Basically, for comparing two separate models (say integrated and segmented models in our case) in terms of their explanatory powers, J test consists of estimating parameters by a least squares regression for the first model (say integrated market case) and then regressing the dependent variable (security return) on the regressors of the second model (say segmented market regressors) and the fitted values of dependent variable from the first model. An asymptotically valid test would be to test if the coefficient on the fitted value in this final regression is significantly different than zero or not, to determine if the first model has some explanatory power over the second model. Obviously the test can be implemented the other way around and the power of second model over the first one can also be tested. In this study, both ways have been exploited to determine which model, integrated market model or segmented market model, has more explanatory power over the other one. 


\section{Sample and Simple Statistics}

The sample consists of monthly returns on stock indices for eight countries plus a value-weighted world index. The sample period covers from December 1973December $1998^{6}$. The indexes are obtained from DataStream. DataStream database contains indexes for 35 financial markets plus several regional indices. For the analysis here, the G7 countries (Canada, France, Germany, Italy, Japan, United Kingdom, and United States) and Switzerland, the largest European market not included in the G7 are selected. National stock indices are defined in their own national currencies. Value weighted world index is obtained by converting individual market data to a common currency of U.S. dollars.

The related monthly exchange rates and consumer price indices have been obtained from International Financial Statistics (IFS) database. The exchange rates are defined as national currency per U.S. dollar. Finally, the leading markets to each country have been obtained from International Trade Statistics Yearbook. This yearbook, for each country, gives the percent of trade accounted for by each of the first ten trading partners. The leading markets for each country are chosen as the most important ones (with a percent of trade equal to or higher than 10\%) among these trading partners.

Table 1, Panel A contains the summary statistics for the data. In all cases, index of skewness and index of kurtosis strongly reject the hypothesis of normally distributed returns. The index of kurtosis is particularly large for U.K. Panel A also contains the unconditional correlations among markets. The values in most cases are below 0.6. The correlation between U.S. and Canada, not surprisingly, is rather high compared to the other correlations, 0.74. The correlations between Switzerland and U.S., Germany and U.K., and U.S. and U.K are also higher than 0.6.

Panel B in the table reports autocorrelations for the returns and the returns squared. Since the autocorrelations of the stock returns are not predominantly significant, the analysis does not need to be corrected for spurious autocorrelation in the market indices. On the other hand, in most cases, significant autocorrelation is detected in short lags for the squared returns. This implies that a GARCH parameterization for the second moments would be appropriate for the stock returns.

Finally, for the squared returns, Panel B presents the cross correlations between the world index and the other assets. It is observed that the squared world index return is consistently correlated with the other squared asset returns at lead 1 . The analysis of other cross correlations among squared returns (not reported) reveals that, with a few exceptions, all cross correlations are contemporaneously correlated.

\footnotetext{
${ }^{6} 2002$ is the year of adoption of Euro, which deserves to be a special case to be analyzed, thus the period between 2002-present remains to be a topic of future study.
} 
Table 1: Sample statistics

\begin{tabular}{|c|c|c|c|c|c|c|c|c|c|}
\hline \multicolumn{10}{|c|}{ PANEL A: Summary statistics of asset returns } \\
\hline Series & $\begin{array}{l}\text { Number } \\
\text { of Obs. }\end{array}$ & Mean & $\begin{array}{l}\text { Std. } \\
\text { Error }\end{array}$ & Minimum & n Maximum & Skewness & $\begin{array}{l}\text { Significance } \\
\text { level }(S k=0)\end{array}$ & $\begin{array}{c}\text { Kurtos } \\
\mathrm{s}\end{array}$ & $\begin{array}{l}\text { Significance } \\
\text { level }(S k=0)\end{array}$ \\
\hline US & 310 & 0.0075 & 0.0438 & -0.2451 & 0.1584 & -0.72 & 0.00000 & 4.33 & 0.000000 \\
\hline Canada & 310 & 0.0059 & 0.0466 & -0.2356 & 0.1516 & -0.79 & 0.00000 & 3.99 & 0.000000 \\
\hline France & 310 & 0.0085 & 0.0634 & -0.2442 & 0.2051 & -0.46 & 0.00091 & 1.79 & 0.000000 \\
\hline Germany & 310 & 0.0058 & \begin{tabular}{|l|l|}
3 & 0.0486 \\
\end{tabular} & -0.2675 & 0.1413 & -0.77 & 0.00000 & 3.73 & 0.000000 \\
\hline Italy & 310 & 0.0100 & 0.0746 & -0.2 & 0.2782 & 0.27 & 0.04926 & 0.97 & 0.000557 \\
\hline Japan & 310 & 0.0041 & 0.0525 & -0.2 & 0.1745 & -0.34 & 0.01379 & 2.25 & 0.000000 \\
\hline UK & 310 & 0.0091 & 0.0599 & -0.3 & \begin{tabular}{|l|l|}
30 & 0.4003 \\
\end{tabular} & 0.29 & 0.03761 & 8.4 & 0.000000 \\
\hline \begin{tabular}{|l|} 
Switzerland \\
\end{tabular} & 310 & 0.0067 & \begin{tabular}{|l|l|} 
& 0.0480 \\
\end{tabular} & -0.2 & 0.1810 & -1.02 & 0.00000 & 5.2 & 0.000000 \\
\hline Uncon & nditional & I correlat & tion matr & trix of & eturns - Mon & nthly Data Fr & From 1973 & 3:03 To & 998:11 \\
\hline & US & Canada & France & Germ & Italy & Japan & UK & $\begin{array}{c}\text { Switzer } \\
\text { nd }\end{array}$ & World \\
\hline US & 1 & 0.742 & 0.520 & 0.4 & 0.319 & 0.311 & 0.640 & 0.642 & 0.027 \\
\hline Canada & & 1 & 0.511 & 0.4 & 0.354 & 0.287 & 0.569 & 0.573 & 0.115 \\
\hline France & & & 1 & 0.5 & 0.493 & 0.320 & 0.528 & 0.576 & 0.114 \\
\hline Germany & & & & 1 & 0.428 & 0.306 & 0.455 & 0.693 & 0.152 \\
\hline Italy & & & & & 1 & 0.285 & 0.391 & 0.448 & 0.140 \\
\hline Japan & & & & & & 1 & 0.328 & 0.389 & 0.192 \\
\hline UK & & & & & & & 1 & 0.605 & 0.105 \\
\hline Switzerland & & & & & & & & 1 & 0.160 \\
\hline World & & & & & & & & & 1 \\
\hline PANEL B: AL & utocorre & elations a & and cross & 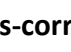 & tion & & & & \\
\hline Autocorrela & ations of & stock re & turns & & & & & & \\
\hline Lag & & 1 & 2 & & 3 & 4 & 5 & & 6 \\
\hline US & & 032 & -0.034 & & 0.001 & -0.014 & 0.05 & & -0.059 \\
\hline Canada & & 044 & -0.041 & & 0.039 & -0.061 & 0.05 & & 0.041 \\
\hline France & & 086 & -0.085 & & 0.084 & 0.022 & 0.04 & & -0.048 \\
\hline Germany & & 090 & -0.053 & & 0.047 & 0.039 & -0.07 & & -0.036 \\
\hline Italy & & $100 *$ & -0.023 & & 0.096* & 0.075 & -0.01 & & 0.057 \\
\hline \begin{tabular}{|l|} 
Japan \\
\end{tabular} & & 066 & -0.032 & & -0.001 & 0.021 & 0.02 & & -0.017 \\
\hline UK & 0.12 & $28^{* *}$ & $-0.096^{*}$ & & 0.053 & 0.038 & -0.12 & $25^{* *}$ & $-0.096 *$ \\
\hline Switzerland & 0.13 & $38^{* *}$ & -0.038 & & 0.018 & -0.013 & 0.05 & & -0.057 \\
\hline World & & $96^{*}$ & -0.029 & & 0.008 & -0.021 & 0.03 & & -0.076 \\
\hline Autocorre & ations of & squared & d stock re & eturn & & & & & \\
\hline US & 0.13 & $38^{* * *}$ & 0.091 & & $0.094^{*}$ & 0.064 & -0.01 & & 0.023 \\
\hline Canada & & .027 & $0.173^{*}$ & $* * *$ & -0.017 & 0.032 & -0.01 & & -0.001 \\
\hline France & & 025 & 0.059 & & 0.002 & $0.184^{* * *}$ & -0.02 & & 0.025 \\
\hline Germany & 0.14 & $13 * * *$ & -0.016 & & 0.072 & 0.058 & 0.04 & & 0.003 \\
\hline Italy & & 064 & -0.026 & & $0.140 * *$ & 0.051 & 0.10 & 09* & 0.037 \\
\hline Japan & 0.28 & $38 * * *$ & $0.126^{\prime}$ & $5 * * *$ & 0.007 & 0.038 & 0.16 & $63 * * *$ & $0.213^{* * *}$ \\
\hline UK & 0.17 & $77 * *$ & $0.142^{\prime}$ & & $0.141^{* *}$ & 0.062 & 0.09 & $98^{*}$ & 0.058 \\
\hline \begin{tabular}{|l|} 
Switzerland \\
\end{tabular} & 0.27 & $71^{* * *}$ & 0.085 & & 0.047 & 0.072 & -0.00 & 07 & -0.007 \\
\hline World & & $105^{*}$ & $0.131^{\prime}$ & & 0.068 & 0.061 & & $96 *$ & $0.096 *$ \\
\hline
\end{tabular}


Sema BAYRAKTAR

Table 1 (cont.) : Sample statistics

\begin{tabular}{|c|c|c|c|c|c|c|c|c|c|c|c|c|c|}
\hline \multicolumn{14}{|c|}{ Cross correlations of squared stock returns with squared world return } \\
\hline Lag & -6 & -5 & -4 & -3 & -2 & -1 & 0 & 1 & 2 & 3 & 4 & 5 & 6 \\
\hline US & 0.003 & $\begin{array}{c}0.148 \\
* * *\end{array}$ & $\begin{array}{c}0.122 \\
* *\end{array}$ & $\begin{array}{c}0.099 \\
*\end{array}$ & 0.055 & $\begin{array}{c}0.742 \\
* * *\end{array}$ & 0.090 & $\begin{array}{c}0.126 \\
*\end{array}$ & 0.076 & 0.012 & 0.030 & 0.076 & 0.003 \\
\hline \begin{tabular}{|l|} 
Canad \\
a \\
\end{tabular} & 0.001 & 0.061 & 0.005 & $\begin{array}{c}0.152 \\
* * * \\
\end{array}$ & 0.023 & \begin{tabular}{|c|c}
0.656 \\
$* * *$
\end{tabular} & -0.063 & 0.082 & -0.034 & -0.015 & -0.005 & 0.038 & -0.032 \\
\hline France & 0.056 & 0.170 & -0.062 & -0.001 & $\begin{array}{c}0.137 \\
* *\end{array}$ & $\begin{array}{c}0.512 \\
* * *\end{array}$ & 0.026 & 0.064 & 0.011 & 0.072 & 0.008 & 0.065 & 0.016 \\
\hline $\begin{array}{l}\text { Germa } \\
\text { ny }\end{array}$ & 0.067 & -0.006 & 0.009 & $\begin{array}{c}0.106 \\
*\end{array}$ & 0.097 & $\begin{array}{c}0.558 \\
* * *\end{array}$ & 0.080 & 0.009 & 0.021 & 0.071 & 0.047 & $\begin{array}{c}0.109 \\
*\end{array}$ & 0.051 \\
\hline Italy & $\begin{array}{c}0.100 \\
*\end{array}$ & 0.072 & -0.068 & 0.009 & 0.020 & $\begin{array}{c}0.194 \\
* * *\end{array}$ & -0.039 & -0.026 & -0.012 & -0.013 & 0.032 & 0.027 & 0.030 \\
\hline Japan & $\begin{array}{c}0.130 \\
* * *\end{array}$ & -0.013 & -0.018 & $\begin{array}{c}0.128 \\
* * *\end{array}$ & 0.054 & $\begin{array}{c}0.461 \\
* * *\end{array}$ & $\begin{array}{c}0.213 \\
* * *\end{array}$ & 0.063 & 0.049 & 0.062 & 0.078 & 0.069 & 0.006 \\
\hline UK & 0.040 & 0.025 & 0.026 & 0.034 & $\begin{array}{c}0.107 \\
*\end{array}$ & $\begin{array}{c}0.550 \\
* * *\end{array}$ & 0.055 & 0.052 & $\begin{array}{c}0.140 \\
* * *\end{array}$ & $\begin{array}{c}0.209 \\
* * *\end{array}$ & $\begin{array}{c}0.133 \\
* * *\end{array}$ & $\begin{array}{c}0.183 \\
* * *\end{array}$ & 0.085 \\
\hline \begin{tabular}{|l|} 
Switze \\
rland
\end{tabular} & 0.055 & $\begin{array}{c}0.103 \\
*\end{array}$ & 0.035 & $\begin{array}{c}0.132 \\
* *\end{array}$ & $\begin{array}{c}0.184 \\
* * *\end{array}$ & $\begin{array}{c}0.641 \\
* * *\end{array}$ & 0.083 & $\begin{array}{c}0.095 \\
*\end{array}$ & 0.011 & 0.006 & -0.004 & $\begin{array}{c}0.121 \\
* *\end{array}$ & 0.020 \\
\hline
\end{tabular}

PANEL C: Dickey-Fuller tests

\begin{tabular}{|l|c|c|c|c|c|c|c|c|}
\multicolumn{2}{|c|}{ PANEL C: Dickey-Fuller tests } \\
\hline \multicolumn{2}{|c|}{ Security Price Level } \\
\hline & DF & $\begin{array}{c}\text { ADF } \\
\text { (lags) }\end{array}$ & $\begin{array}{c}\text { DF (with } \\
\text { trend) }\end{array}$ & $\begin{array}{c}\text { ADF (lags) } \\
\text { (with } \\
\text { trend) }\end{array}$ & DF & ADF (lags) & $\begin{array}{c}\text { DF (with } \\
\text { trend) }\end{array}$ & $\begin{array}{c}\text { ADF (lags) } \\
\text { (with } \\
\text { trend) }\end{array}$ \\
\hline US & 1.68 & $\begin{array}{c}1.43 \\
(12)\end{array}$ & -11.85 & $\begin{array}{c}-13.04 \\
(12)\end{array}$ & $\begin{array}{c}-299.03 \\
* * *\end{array}$ & $\begin{array}{c}-152.55 \\
(12)^{* * *}\end{array}$ & $\begin{array}{c}-304.80 \\
* * *\end{array}$ & $\begin{array}{c}-674.03 \\
(12)^{* * *}\end{array}$ \\
\hline Canada & 0.29 & $\begin{array}{c}0.31 \\
(12)\end{array}$ & -16.27 & $\begin{array}{c}-35.32 \\
(12)^{* * *}\end{array}$ & $\begin{array}{c}-295.52 \\
* * *\end{array}$ & $\begin{array}{c}11530.78 \\
(12)^{* * *}\end{array}$ & $\begin{array}{c}-296.39 \\
* * *\end{array}$ & $\begin{array}{c}948.74 \\
(12)^{* * *}\end{array}$ \\
\hline France & 0.12 & $\begin{array}{c}-0.10 \\
(12)\end{array}$ & -12.90 & $\begin{array}{c}-29.76 \\
(12)^{* * *}\end{array}$ & $\begin{array}{c}-282.36 \\
* * *\end{array}$ & $\begin{array}{c}-138.97 \\
(12)^{* * *}\end{array}$ & $\begin{array}{c}-283.03 \\
* * *\end{array}$ & $\begin{array}{c}-155.76 \\
(12)^{* * *}\end{array}$ \\
\hline Germany & 0.78 & $\begin{array}{c}0.53 \\
(6)\end{array}$ & -12.51 & $\begin{array}{c}-13.18 \\
(6)\end{array}$ & $\begin{array}{c}281.10 \\
* * *\end{array}$ & $\begin{array}{c}-102.32 \\
(12)^{* * *}\end{array}$ & $\begin{array}{c}-283.02 \\
* * *\end{array}$ & $\begin{array}{c}-116.49 \\
(12)^{* * *}\end{array}$ \\
\hline Italy & -0.42 & $\begin{array}{c}-0.93 \\
(6)\end{array}$ & -4.74 & $\begin{array}{c}-9.08 \\
(6)\end{array}$ & $\begin{array}{c}-278.04 \\
* * *\end{array}$ & $\begin{array}{c}-54.28 \\
(12)^{* * *}\end{array}$ & $\begin{array}{c}-278.12 \\
* * *\end{array}$ & $\begin{array}{c}-55.03 \\
(12)^{* * *}\end{array}$ \\
\hline Japan & -1.41 & $\begin{array}{c}-1.67 \\
(6)\end{array}$ & -1.33 & $\begin{array}{c}-1.47 \\
(6)\end{array}$ & $\begin{array}{c}-288.53 \\
* * *\end{array}$ & $\begin{array}{c}-286.48 \\
(6)^{* * *}\end{array}$ & $\begin{array}{c}-289.66 \\
* * *\end{array}$ & $\begin{array}{c}-320.90 \\
(6)^{* * *}\end{array}$ \\
\hline UK & -0.04 & $\begin{array}{c}-0.09 \\
(6)\end{array}$ & $-22.58 * *$ & $\begin{array}{c}-31.22 \\
(6) * * *\end{array}$ & $\begin{array}{c}-269.45 \\
* * *\end{array}$ & $\begin{array}{c}-3586.68 \\
(6)^{* * *}\end{array}$ & $\begin{array}{c}-269.75 \\
* * *\end{array}$ & $\begin{array}{c}-4557.04 \\
(6)^{* * *}\end{array}$ \\
\hline Switzerland & 1.89 & $\begin{array}{c}1.54 \\
(12)\end{array}$ & -8.58 & $\begin{array}{c}-10.24 \\
(12)\end{array}$ & $\begin{array}{c}-266.30 \\
* * *\end{array}$ & $\begin{array}{c}-84.81 \\
(12)^{* * *}\end{array}$ & $\begin{array}{c}-272.54 \\
* * *\end{array}$ & $\begin{array}{c}-195.54 \\
(12)^{* * *}\end{array}$ \\
\hline World & -0.22 & $\begin{array}{c}0.41 \\
(12)\end{array}$ & -10.99 & $\begin{array}{c}-17.72 \\
(12)\end{array}$ & $\begin{array}{c}-278.45 \\
* * *\end{array}$ & $\begin{array}{c}-101.33 \\
(12)^{* * *}\end{array}$ & $\begin{array}{c}-279.40 \\
* * *\end{array}$ & $\begin{array}{c}-107.78 \\
(12)^{* * *}\end{array}$ \\
\hline
\end{tabular}


Table 1 (cont.) : Sample statistics

\begin{tabular}{|l|c|c|c|c|c|c|c|c|}
\hline \multicolumn{7}{|c|}{ Consumer Price Index } \\
\hline
\end{tabular}

Statistical significance at the $10 \%, 5 \%$, and $1 \%$ level is indicated by $*, * *, * * *$ respectively

The series (stock prices, stock returns, consumer price indices and inflations) are also tested for their stationary characteristics by using Dickey-Fuller unit root tests. Since the number of observations is equal to 310 , the critical value of the test for case without trend is -14.0 and approximately -20.3 at 0.05 and 0.01 significance levels, respectively. For the test with trend it is equal to approximately -21.3, and 28.4 at 0.05 and 0.01 significance levels respectively. It is seen in Panel $C$ that in most cases the null hypothesis that the series has unit root cannot be rejected for the levels of series (security price levels and consumer price indices). However, the null is consistently rejected for their first difference (stock returns and inverse of inflations). This implies that stock returns and inverse of inflations are stationary.

\section{Structural Break Points}

It is quite possible that the structural relationship between dependent and independent variables changes during the full period of 1973-1998. This may weaken the significance of results if the test is trying to explore only one type of relationship for the full period. Thus, the regressions have been tested not only for the full period but also for the sub-periods for which the structure of the regression is assumed to change. The main question here is related to determining the break points where the structural changes are assumed to occur. Thus, by using the information obtained from Cusum Squares test, $s_{r}$, and Quandt's log likelihood ratio, $\lambda_{r}$, first the break points have been determined for each country separately. 
Then Chow test ${ }^{7}$ has been used as a final decision maker to determine the subperiods. Table 2 reports the structural break points implied by cusum squares test, $s_{r}$, and Quandt's log likelihood ratio, $\lambda_{r}$, and the related Chow statistics for these break points. Chow tests are consistently significant at $1 \%$ level indicating that the model changes its structure by moving from pre-break point period to post-break point period.

Table 2: Structural Break Points and Statistics for Testing the Model Stability

\begin{tabular}{|l|c|l|l|l|l|l|}
\hline Country & Break Point & Chow Test & Break Point & Chow Test & Break Point & Chow Test \\
\hline US & $\begin{array}{c}\text { March } \\
1975\end{array}$ & $23.35^{* * *}$ & $\begin{array}{c}\text { November } \\
1987\end{array}$ & $35.32^{* * *}$ & June 1990 & $76.63^{* * *}$ \\
\hline Canada & $\begin{array}{c}\text { November } \\
1982\end{array}$ & $21.01^{* * *}$ & $\begin{array}{c}\text { November } \\
1987\end{array}$ & $46.46^{* * *}$ & & \\
\hline France & $\begin{array}{c}\text { August } \\
1981\end{array}$ & $22.13^{* * *}$ & $\begin{array}{c}\text { November } \\
1987\end{array}$ & $51.81^{* * *}$ & $\begin{array}{c}\text { March } \\
1991\end{array}$ & $69.34^{* * *}$ \\
\hline Germany & $\begin{array}{c}\text { February } \\
1981\end{array}$ & $34.70^{* * *}$ & $\begin{array}{c}\text { November } \\
1987\end{array}$ & $16.30^{* * *}$ & & \\
\hline Italy & $\begin{array}{c}\text { November } \\
1981\end{array}$ & $28.70^{* * *}$ & $\begin{array}{c}\text { June } 1986 \\
71.38^{* * *}\end{array}$ & June 1991 & $54.44^{* * *}$ \\
\hline Japan & $\begin{array}{c}\text { August } \\
1979\end{array}$ & $102.66^{* * *}$ & $\begin{array}{c}\text { March } \\
1986\end{array}$ & $80.67^{* * *}$ & $\begin{array}{c}\text { January } \\
1990\end{array}$ & $17.40^{* * *}$ \\
\hline UK & $\begin{array}{c}\text { September } \\
1975\end{array}$ & $18.69^{* * *}$ & $\begin{array}{l}\text { November } \\
1987\end{array}$ & $46.54^{* * *}$ & November \\
1992 & $116.53^{* * *}$ \\
\hline Switzerland & $\begin{array}{c}\text { September } \\
1983\end{array}$ & $41.68^{* * *}$ & July 1987 & $40.74^{* * *}$ & May 1991 & $30.46^{* * *}$ \\
\hline
\end{tabular}

It is possible to come up with some satisfactory economic explanations for these statistical break points. They roughly overlap with the institutional exchange regime change periods for each country. The first break points, overall, are spread over an eight-year span. However, this eight-year period can be considered as a transitory period after the break-down of Bretton Woods Agreement: the transition from fixed exchange rate regimes to dirty floating exchange regimes. For example, for Japan, 1979 is the year when restrictions on capital inflows began to be loosened and December 1, 1980 is the date when exchange controls have been abolished by Foreign Exchange and Trade Control Law. Since the breakdown of Bretton Woods Agreement European countries continued the joint float of their respective currencies. Finally, in March 13, 1979 European Monetary System (EMS) was established. Moreover, Germany relaxed exchange controls related to the purchase of German securities by non-residents during 1980s. In the case of Switzerland, 'Swiss franc denominated securities' had been available to non-

\footnotetext{
${ }^{7}$ [9] treats the cusum squares test as suggestive of structural change rather than a formal test of parameter stability. In addition, there is no test developed for Quandt's log likelihood ratio. Moreover, Chow test is a more powerful test than $s_{r}$. For all these reasons, Chow test is used as a final decision maker here.
} 
residents and the requirement that "foreigners' subscriptions to any issue of 'foreign bonds denominated in Swiss franc' could not exceed 50\%" was abolished starting from 24 January 1979. France and Italy have experienced their exchange regime liberalization in mid-1980s (Chelley-Steeley, Pentecost, E.J., \& Steeley, J., 1998).

In summary, the global liberalization programs have continuously reduced the exchange controls since the break-down of Bretton Woods. Since the markets have opened up, they also became more integrated than they were in the past. Because of this integration effect, the second and third break points, if any, are observed to be very close to each other for all countries. The second break point captures the famous Black Monday (19 October 1987) effect on the markets. Only for Japan and Italy, it seems like the structural change occurred before the other markets. This may be due to the fact that although all countries were experiencing a gradual liberalization in their exchange regimes, these two countries' liberalization had been slower than the others and they have experienced very important changes just before the crash. In September 22, 1985, the Group Five (France, the federal Republic of Germany, Japan, United Kingdom and United States) declared that "exchange rates did not fully reflect fundamental economic conditions, that further measures aimed at opening markets would be important in resisting protectionism, and that the members of the Group Five agreed that some further orderly appreciation of the main non-dollar currencies against the US dollar would be desirable, and expressed their readiness to cooperate more closely to encourage such a development when to do so would be helpful ( IMF-Annual Report on Exchange Arrangements and Exchange Restrictions 1985)".

Thus, Italy and especially Japan might have experienced a change in the pace of opening their financial markets just before the crash and entered a structural change before any other country.

The liberalization of the financial markets made the EMS extremely vulnerable to speculation. This has led to the successful speculative attacks on almost all participating currencies (especially on the Italian lira and the British pound), eventually leading to the collapse of the system in August 1993. In September 16, 1992 United Kingdom has suspended the intervention obligations with respect to exchange and the intervention mechanism of the EMS. In September 17, 1992 the Italy temporarily withdrew from the exchange rate and the intervention mechanism of the EMS, and the lira was allowed to float. In 1993, the relatively small fluctuation margins of $\pm 2.25 \%$ for the bilateral rates were enlarged to $15 \%$ for all countries in EMS, except for the Dutch guilder/Deutschmark (DM) rate. United States and Japan has continued to liberalize their financial markets. In Japan, the system of foreign deposit accounts was liberalized on July 30, 1990. In United States, the Federal Reserve Board's decision (of December 23, 1988) allowing U.S. banks to accept foreign currency deposits became effective on 
December 31, 1989. The third break point reflects all these dramatic changes in the economies of these countries.

\section{Empirical Evidence on International Asset Pricing Models}

The models for integrated and segmented market cases are tested and compared for both entire period and the specific sub-periods for each country. The objective of these tests are two-fold; first one is to examine whether the exchange rate variables are significant in explaining the asset pricing relations regardless of the models and second one is to examine which model is a better one in explaining the security pricing relations.

Table 3 presents the point estimates of the coefficients and t-statistics computed using robust standard errors of the integrated market model for the entire period.

Table 3: Parameter Estimation in Integrated Market Case (Full Period (1973:02-1998:12))

\begin{tabular}{|l|c|c|c|c|}
\hline Country & Constant & $\operatorname{COV}\left(\mathrm{R}_{\mathrm{i}}, \mathrm{R}_{\mathrm{M}}\right)$ & $\operatorname{COV}\left(\mathrm{R}_{\mathrm{M}}, 1 / \mathrm{I}_{\mathrm{i}}\right)$ & $\mathrm{E}\left(1 / \mathrm{I}_{\mathrm{i}}\right)$ \\
\hline \multirow{2}{*}{ US } & $8.3256 \mathrm{e}-003$ & -0.53 & $-6.5729 \mathrm{e}-007$ & $2.3274 \mathrm{e}-009$ \\
& $\left(3.2^{* * *}\right)$ & $(-1.5)$ & $\left(-1.7^{*}\right)$ & $(0.5)$ \\
\hline \multirow{2}{*}{ Canada } & 0.003 & 3.23 & 0.000012 & -0.000000147 \\
& $(0.9)$ & $\left(1.8^{*}\right)$ & $(0.5)$ & $(-1.0)$ \\
\hline \multirow{2}{*}{ France } & 0.007 & 2.53 & 0.000008 & -0.000000047 \\
& $\left(1.8^{*}\right)$ & $(0.6)$ & $\left(2.1^{* *}\right)$ & $(-0.6)$ \\
\hline \multirow{2}{*}{ Germany } & 0.007 & -6.40 & -0.000001 & 0.00000009 \\
& $\left(2.7^{* * *}\right)$ & $\left(-5.2^{* * *}\right)$ & $(-0.0)$ & $(0.2)$ \\
\hline \multirow{2}{*}{ Italy } & $2.7879 \mathrm{e}-003$ & 18.68 & $3.9749 \mathrm{e}-006$ & $-7.3487 \mathrm{e}-008$ \\
& $(0.5)$ & $\left(2.4^{* *}\right)$ & $(1.2)$ & $\left(-4.1^{* * *}\right)$ \\
\hline \multirow{2}{*}{ Japan } & 0.0016 & 3.03 & 0.000004 & 0.0000004 \\
& $(0.4)$ & $\left(2.6^{* * *}\right)$ & $(0.2)$ & $(0.9)$ \\
\hline \multirow{2}{*}{ UK } & $8.1060 \mathrm{e}-003$ & 2.17 & $-5.3660 \mathrm{e}-006$ & $-6.1046 \mathrm{e}-008$ \\
& $\left(2.5^{* * *}\right)$ & $(0.6)$ & $(-1.1)$ & $\left(-7.6^{* * *}\right)$ \\
\hline \multirow{2}{*}{ Switzerland } & $8.8561 \mathrm{e}-003$ & -10.06 & $-4.9957 \mathrm{e}-006$ & $1.7879 \mathrm{e}-007$ \\
& $\left(3.1^{* * *}\right)$ & $\left(-2.2^{* *}\right)$ & $(-0.2)$ & $(1.9 *)$ \\
\hline
\end{tabular}

(Statistical significance at the $10 \%, 5 \%$, and $1 \%$ level is indicated by $*, * * * *$ respectively, $\mathrm{t}$ values are in parentheses)

Unfortunately, none of the explanatory variables are significant consistently for all countries. The point estimates of the market risk are significant in five cases, while the point estimates of the exchange rate risks are significant only in five cases, in total. However, the more unfortunate fact is that the sings of the regressors are mixed, thus not in consistency with the theory. The classic CAPM and the asset pricing model with exchange rate here (Exchange Rate CAPM, ER-CAPM from now on) predicts a positive coefficient for the market risk. From the table, the market premium is statistically negative for two out of five cases where it is significant. ERCAPM also predicts positive premium for covariance of the market return with the 
inverse-inflation index (inflation-market risk) and negative premium for expected value of the inverse-inflation (inflation risk). However, market-inflation risk premium is negative in one out of two significant cases and inflation risk premium is positive in one out of three significant cases. Moreover, the constant term, which is predicted to be equal to zero by both classic CAPM and ER-CAPM, is significant in five out of eight cases. Thus, the integrated market results for the entire period do not provide support for neither of the theories.

As mentioned before, to capture, at least partially, the time varying characteristics of the risk premiums integrated market model is analyzed for the sub-periods for each of which it has been determined that regression relation changes its structure. Table 4 reports the estimation results from this analysis. The results for sub-periods have both similarities and differences from those of entire period. They are different because now the number of times the exchange rate risks are significant has increased compared to the full period. Market-inflation risk is significant for 12 , inflation risk is significant for 16 , and market risk is significant for 15 cases out of 30 cases. These numbers are not large enough to claim that these variables are priced in asset pricing relations. However, they cannot totally be attributed to the randomness, either. The sub-period results are not different from entire period results because the flaw that the signs of the coefficients are not consistent with the theory still exists in sub-period analysis. There are only 4 sub-periods where all three variables are significant: the third sub-period for France and the fourth subperiods for Italy, United Kingdom, and Switzerland. This is reasonable since one would expect the level of integration of the markets is increasing in time, thus an integrated market model would be more valid for the recent periods.

A number of diagnostic tests on residuals (not reported) are also implemented to test the specification of the model. The Durbin-Watson tests for the first order serial correlation of the residuals, in most cases, are close to 2 . This implies the absence of first order serial correlation of the residuals. The Ljung-Box tests for higher order correlation of residuals also fail (except three cases) to reject the null that higher order serial correlations are different from zero, thus implying that GARCH $(1,1)$ parameterization that is adopted here is satisfactory. However, the adjusted R2s are rather low for most of cases. This statistics reaches its highest values of $2.1 \%$ and $2.5 \%$ for Switzerland and Germany respectively for the full period. However, for the first and last sub periods of United Kingdom and the last sub period of Switzerland, it improves to be $10 \%, 10 \%$ and $20 \%$ respectively.

As a second step to analyze whether the exchange rate risks are important in asset pricing or not, the regressions from segmented market are examined. Unfortunately, Canada case had to be excluded. There was a two-fold problem that made the would-be regression results for Canada unreasonable; the regressors had very small fluctuations, basically they were constants, and well-known multicollinearity problem. For Switzerland and France, which also suffered from multicollinearity, it was possible to obtain some reasonable results by simply ignoring the variables with high collinearity. 
Table 4: Parameter Estimation in Integrated Market Case (Sub-periods)

\begin{tabular}{|c|c|c|c|c|c|}
\hline Country & Periods & Constant & $\operatorname{cov}\left(R_{i}, R_{M}\right)$ & $\operatorname{COV}\left(R_{M}, 1 / I_{i}\right)$ & $E\left(1 / I_{i}\right)$ \\
\hline \multirow{4}{*}{ US } & $(73: 02-81: 11)$ & $0.008(0.5)$ & $16.7\left(2.7^{* * *}\right)$ & $0.0000004(0.7)$ & $-0.000008\left(-1.7^{*}\right)$ \\
\hline & $(81: 12-86: 06)$ & $0.03\left(2.0^{* *}\right)$ & $-4.5(-0.7)$ & 0.0000009 (1.1) & $-0.00000007(-0.1)$ \\
\hline & $\mid(86: 07-91: 06)$ & $-6.1 e-003(-1.0)$ & $-0.4(-1.3)$ & $-9.9 e-007\left(-1.7^{*}\right)$ & $3.9 \mathrm{e}-010(0.1)$ \\
\hline & $(91: 07-98: 12)$ & $-0.02(-0.7)$ & $-7.7(-1.0)$ & $-0.000002\left(-3.8^{* * *}\right)$ & $-0.00000006(-0.6)$ \\
\hline \multirow{3}{*}{ Canada } & $(73: 02-82: 11)$ & $0.003(0.5)$ & $1.1(0.4)$ & $-0.00005(-1.3)$ & $-0.000001(-1.2)$ \\
\hline & $(82: 12-87: 11)$ & $0.006(1.0)$ & $2.7\left(2.0^{* *}\right)$ & $-0.0000002(-0.0)$ & $0.0000012\left(3.3^{* * *}\right)$ \\
\hline & (87:12-98:12) & $0.003(0.7)$ & $3.7(1.4)$ & $0.00005\left(3.7^{* * *}\right)$ & $-0.0000002\left(-2.4^{* *}\right)$ \\
\hline \multirow{4}{*}{ France } & (73:02-81:08) & $0.003(0.4)$ & $1.9(0.3)$ & $0.00002\left(2.1^{* *}\right)$ & $-0.0000002\left(-7.1^{* * *}\right)$ \\
\hline & $(81: 09-87: 11)$ & $0.02\left(1.9^{*}\right)$ & $-4.1(-1.6)$ & $-0.000001(-0.2)$ & $0.00000007\left(2.7^{* * *}\right)$ \\
\hline & $(87: 12-91: 03)$ & $0.002(0.2)$ & $16.2\left(2.2^{* *}\right)$ & $0.00005\left(2.3^{* *}\right)$ & $0.000001\left(1.6^{*}\right)$ \\
\hline & (91:04-98:12) & $-0.0007(-0.1)$ & $40.0\left(3.7^{* * *}\right)$ & $0.00003(0.8)$ & $0.0000004\left(2.5^{* *}\right)$ \\
\hline \multirow{3}{*}{ Germany } & $(73: 02-81: 02)$ & $-0.001(-0.3)$ & $-5.7(-1.0)$ & $0.0001(1.9 *)$ & $0.0000004\left(1.9^{*}\right)$ \\
\hline & $(81: 03-87: 11)$ & $0.01\left(2.1^{* *}\right)$ & $-16.8(-3.0 * * *)$ & $5.5 e-005(0.6)$ & $1.7 e-007(3.6 * * *)$ \\
\hline & $(87: 12-98: 12)$ & $0.01\left(2.6^{* * *}\right)$ & $-6.3\left(-5.5^{* * *}\right)$ & $0.000001(0.0)$ & $-0.00000009(-0.9)$ \\
\hline \multirow{4}{*}{ Italy } & (73:02-81:11) & $0.008(0.5)$ & $2.9(0.2)$ & $0.000002(0.3)$ & $0.0000004(0.7)$ \\
\hline & $(81: 12-86: 06)$ & $0.03(2.0 * *)$ & $-16.8(-1.2)$ & $-8.4 \mathrm{e}-006\left(-1.8^{*}\right)$ & $-1.1 e-008(-0.6)$ \\
\hline & $\mid(86: 07-91: 06)$ & $-6.1 e-003(-1.0)$ & $21.5(1.4)$ & $5.4 \mathrm{e}-006(0.8)$ & $-8.9 \mathrm{e}-008\left(-9.7^{* * *}\right)$ \\
\hline & (91:07-98:12) & $-0.02(-0.7)$ & $54.8\left(2.1^{* *}\right)$ & $1.9 \mathrm{e}-005\left(3.4^{* * *}\right)$ & $-1.4 \mathrm{e}-007\left(-6.7^{* * *}\right)$ \\
\hline \multirow{4}{*}{ Japan } & $(73: 02-79: 08)$ & $0.004(1.0)$ & $-3.9(-1.3)$ & $0.00008(0.6)$ & $0.00000005(0.0)$ \\
\hline & (79:09-86:03) & $0.009\left(2.7^{* * *}\right)$ & $2.1(0.9)$ & $0.0000007(0.0)$ & $0.000001\left(2.0^{* *}\right)$ \\
\hline & $(86: 04-90: 01)$ & $0.02(1.3)$ & $3.5(0.6)$ & $0.00002(0.4)$ & $0.000002(1.3)$ \\
\hline & (90:02-98:12) & $-0.01\left(-1.7^{*}\right)$ & $4.4\left(4.2^{* * *}\right)$ & $0.000002(0.1)$ & $-0.00000004(-0.1)$ \\
\hline \multirow{4}{*}{ UK } & $(73: 02-75: 09)$ & $-0.04\left(-1.6^{*}\right)$ & $10.2(6.6 * * *)$ & $0.0001(0.5)$ & $0.00002(1.2)$ \\
\hline & $(75: 10-87: 11)$ & $0.01(1.5)$ & $6.6\left(2.1^{* *}\right)$ & $-0.0003(-0.1)$ & $-0.0000009\left(-2.4^{* *}\right)$ \\
\hline & $\mid(87: 12-92: 11)$ & $0.01(1.4)$ & $-5.7(-5.0 * * *)$ & $0.0003(0.5)$ & $0.00000009(1.4)$ \\
\hline & $(92: 12-98: 12)$ & $0.01\left(2.8^{* * *}\right)$ & $-17.2(-4.6 * * *)$ & $-1.4 \mathrm{e}-005\left(-4.3^{* * *}\right)$ & $-7.5 \mathrm{e}-008(-13.9 * * *)$ \\
\hline \multirow{4}{*}{$\begin{array}{l}\text { Switzerla } \\
\text { nd }\end{array}$} & (73:02-83:09) & $2.8 \mathrm{e}-004(0.1)$ & $-11.6\left(-2.1^{* *}\right)$ & $-1.7 e-005(-0.8)$ & $-7.7 e-009(-0.2)$ \\
\hline & $\mid(83: 10-87: 07)$ & $0.01\left(2.8^{* * *}\right)$ & $10.7(0.8)-$ & $-0.00005\left(-1.6^{*}\right)$ & $-0.0000003\left(-1.8^{*}\right)$ \\
\hline & $|(87: 08-91: 05)|$ & $0.01(1.6)$ & $6.3\left(-1.7^{*}\right)$ & $0.00004\left(2.6^{* * *}\right)$ & $-0.0000003(-0.4)$ \\
\hline & (91:06-98:12) & $0.02\left(4.8^{* * *}\right)$ & $-45.7\left(-2.9^{* * *}\right)$ & $-1.4 \mathrm{e}-004\left(-2.8^{* * *}\right)$ & $2.2 \mathrm{e}-007\left(5.6^{* * *}\right)$ \\
\hline
\end{tabular}

(Statistical significance at the $10 \%, 5 \%$, and $1 \%$ level is indicated by $* * * * * *$ respectively, $\mathrm{t}$ values are in parentheses)

Table 5 reports the point estimates of the coefficients and t-statistics computed using robust standard errors of the segmented market model for the entire period. These results are not very much different from those found in integrated market model analysis. The signs of the coefficients are mixed. The coefficients are not consistently significant for all countries. For two countries (Germany, and United Kingdom) none of segmented market model variables is significant in explaining these particular countries' equity returns. On the other hand, for United States all segmented market model variables are found to be significant. The sub-period results (Table 6) do not make many changes in these results. In 11 cases out of 27 cases, at least four of the segmented variables are significant. On the other hand, in 5 out of 27 cases, none of them are significant. Diagnostic tests on residuals for the segmented market model regressions are also implemented. Durbin Watson and the Ljung-Box tests (except two cases; first sub-periods of United States and United Kingdom) imply the absence of any first or higher order correlation for both full and 
sub-period samples. The adjusted $R^{2} s$ are rather low for most of cases. This statistics reaches its highest values of $3.5 \%$ and $3.0 \%$ for United States and Italy respectively for the full period. However, for the sub-period regressions, for some cases it reaches rather large values; it is equal to $19 \%$ and $16 \%$ for the third and fourth sub-periods of France, to $14.5 \%$ and $10 \%$ for the second and third subperiods of Switzerland, to $28 \%$ for the second sub-period for Germany, to $25 \%$ for the second sub-period of Japan, and to $18 \%$ for the third sub-period of United States.

Table 5: Parameter Estimation in Segmented Market Case (Full Period (1973:02-1998:12))

\begin{tabular}{|c|c|c|c|c|c|c|c|}
\hline Country & Constant & $\operatorname{VAR}\left(\mathrm{R}_{\mathrm{i}}\right)$ & $\operatorname{COV}\left(R_{i}, 1 / I_{i}\right)$ & $\operatorname{COV}^{2}\left(R_{i}, 1 / l_{i}\right)$ & $\operatorname{cov}\left(R_{i}, 1 / I_{i}^{*}\right)$ & $\operatorname{Cov}^{2}\left(R_{i}, 1 / I_{i}^{*}\right)$ & $\begin{array}{c}{\left[\operatorname{COV}\left(\mathrm{R}_{\mathrm{i}}, 1 / \mathrm{I}_{\mathrm{i}}\right)^{*}{ }^{\operatorname{COV}\left(\mathrm{R}_{\mathrm{i}}, 1 /{ }^{\prime}{ }_{\mathrm{i}}\right]}\right.} \\
\end{array}$ \\
\hline US & $\begin{array}{c}-2.2 \mathrm{e}-003 \\
(-0.5)\end{array}$ & $\begin{array}{c}3.0 \\
\left(1.8^{*}\right)\end{array}$ & $\begin{array}{c}-8.0 \mathrm{e}-006 \\
\left(-1.9^{*}\right)\end{array}$ & $\begin{array}{c}-2.2 \mathrm{e}-009 \\
\left(-3.2^{* * *}\right)\end{array}$ & $\begin{array}{c}-3.9 e-006 \\
\left(-2.0^{* *}\right)\end{array}$ & $\begin{array}{l}2.7 e-010 \\
\left(2.9^{* * *}\right)\end{array}$ & $\begin{array}{l}-2.3 e-009 \\
(-2.5 * * *)\end{array}$ \\
\hline France & $\begin{array}{c}0.03 \\
\left(2.3^{* *}\right) \\
\end{array}$ & $\begin{array}{c}-4.7 \\
\left(-1.7^{*}\right) \\
\end{array}$ & $\begin{array}{c}1.5 \mathrm{e}-006 \\
(1.6)\end{array}$ & NA & $\begin{array}{c}5.9 e-007 \\
\left(1.7^{*}\right)\end{array}$ & NA & $\begin{array}{c}5.8 \mathrm{e}-011 \\
(0.8)\end{array}$ \\
\hline Germany & $\begin{array}{c}0.02 \\
\left(1.9^{*}\right) \\
\end{array}$ & $\begin{array}{c}-5.4 \\
(-1.4) \\
\end{array}$ & $\begin{array}{c}-8.7 e-006 \\
(-0.3)\end{array}$ & $\begin{array}{c}5.1 \mathrm{e}-009 \\
(0.9)\end{array}$ & $\begin{array}{c}7.3 e-006 \\
(1.0)\end{array}$ & $\begin{array}{c}-2.8 \mathrm{e}-010 \\
(-0.3)\end{array}$ & $\begin{array}{c}1.5 e-009 \\
(0.3)\end{array}$ \\
\hline Italy & $\begin{array}{c}0.2 \\
\left(1.6^{*}\right)\end{array}$ & $\begin{array}{l}-37.2 \\
(-1.6) \\
\end{array}$ & $\begin{array}{c}2.5 \mathrm{e}-005 \\
(1.6)\end{array}$ & $\begin{array}{c}8.9 e-009 \\
\left(2.1^{* *}\right)\end{array}$ & $\begin{array}{c}\text { 3.1e-005 } \\
(1.0)\end{array}$ & $\begin{array}{c}-9.8 e-010 \\
(-0.7)\end{array}$ & $\begin{array}{c}8.2 \mathrm{e}-008 \\
\left(2.1^{* *}\right)\end{array}$ \\
\hline Japan & $\begin{array}{c}-3.1 \mathrm{e}-004 \\
(-0.1)\end{array}$ & $\begin{array}{c}0.8 \\
\left(2.0^{* *}\right) \\
\end{array}$ & $\begin{array}{c}4.8 \mathrm{e}-006 \\
(1.1)\end{array}$ & $\begin{array}{c}-8.9 e-010 \\
\left(-3.5^{* * *}\right)\end{array}$ & $\begin{array}{c}2.60 \mathrm{e}-006 \\
(1.4)\end{array}$ & $\begin{array}{c}-7.5 e-011 \\
\left(-2.4^{* *}\right)\end{array}$ & $\begin{array}{c}-2.7 e-010 \\
(-0.8)\end{array}$ \\
\hline UK & $\begin{array}{l}10.9 \\
(0.7) \\
\end{array}$ & $\begin{array}{c}1.4 \\
(1.4) \\
\end{array}$ & $\begin{array}{l}0.04 \\
(0.6) \\
\end{array}$ & $\begin{array}{c}0.00002 \\
(0.5) \\
\end{array}$ & $\begin{array}{c}-0.006 \\
(-0.8) \\
\end{array}$ & $\begin{array}{c}-0.000001 \\
(-1.1) \\
\end{array}$ & $\begin{array}{c}-0.00002 \\
(-0.9) \\
\end{array}$ \\
\hline $\begin{array}{l}\text { Switzerlan } \\
\text { d }\end{array}$ & $\begin{array}{c}0.02 \\
\left(2.9^{* * *}\right) \\
\end{array}$ & $\begin{array}{c}-4.7 \\
\left(-1.9^{* *}\right) \\
\end{array}$ & $\begin{array}{c}-1.1 \mathrm{e}-006 \\
\left(1.9^{* *}\right)\end{array}$ & NA & $\begin{array}{c}-2.2 \mathrm{e}-008 \\
\left(-1.7^{*}\right) \\
\end{array}$ & NA & NA \\
\hline
\end{tabular}

Table 6: Parameter Estimation in Segmented Market Case (Sub-periods)

\begin{tabular}{|c|c|c|c|c|c|c|c|c|}
\hline $\begin{array}{l}\text { Countr } \\
y\end{array}$ & Periods & Constant & $\operatorname{VAR}\left(\mathrm{R}_{\mathrm{i}}\right)$ & $\operatorname{COV}\left(R_{i}, 1 / I_{i}\right)$ & $\operatorname{COV}^{2}\left(R_{i}, 1 / l_{i}\right)$ & $\operatorname{cov}\left(R_{i}, 1 / I_{i}^{*}\right)$ & $\operatorname{cov}^{2}\left(R_{i}, 1 / I_{i}^{*}\right)$ & $\begin{array}{c}{\left[\operatorname{COV}\left(R_{i}, 1 / I_{i}\right)^{*}\right.} \\
\operatorname{Cov}\left(R_{i}, 1 / I_{1}^{*}\right]\end{array}$ \\
\hline \multirow{8}{*}{ US } & (73:02- & -0.06 & 14.0 & $4.5 e-005$ & $1.0 \mathrm{e}-008$ & $-3.6 e-005$ & $-4.3 e-009$ & $-1.1376 \mathrm{e}-008$ \\
\hline & 75:03) & $\left(-6.2^{* * *}\right)$ & $(8.0 * * *)$ & $\left(4.2^{* * *}\right)$ & $\left(5.1^{* * *}\right)$ & $\left(-4.3^{* * *}\right)$ & $-2.8 e-009$ & $(-17.9 * * *)$ \\
\hline & (75:04- & -0.02 & 8.7 & $-2.3 e-005$ & $-1.1 e-008$ & $-1.4 e-005$ & $\left(-3.1^{* * *}\right)$ & $-1.6 e-008$ \\
\hline & $87: 11)$ & $(-2.5 * * *)$ & $\left(4.5^{* * *}\right)$ & $\left(-1.6^{*}\right)$ & $\left(-2.2^{* *}\right)$ & $(-1.2)$ & $(-1.0)$ & $\left(-2.3^{* *}\right)$ \\
\hline & (87:12- & $2.3 e-003$ & 0.2 & $-2.6 e-005$ & $-4.4 e-009$ & $-6.8 e-006$ & $4.4 \mathrm{e}-010$ & $-4.2 e-009$ \\
\hline & $90: 06)$ & $(0.4)$ & $(0.5)$ & $(-3.0 * * *)$ & $(-2.9 * * *)$ & $\left(-2.2^{* *}\right)$ & $(2.6 * * *)$ & $\left(-2.2^{* *}\right)$ \\
\hline & (90:07- & $4.9 e-003$ & 4.5 & $-2.0 e-006$ & $-1.7 e-008$ & $-1.5 e-006$ & $4.0 e-009$ & $-3.0 e-008$ \\
\hline & $98: 12)$ & $(0.8)$ & $(1.4)$ & $(-0.1)$ & $\left(-2.5^{* *}\right)$ & $(-0.1)$ & $(1.2)$ & $(-2.0 * *)$ \\
\hline \multirow{8}{*}{ France } & (73:02- & $1.7 e-003$ & -0.1 & $-3.1 e-006$ & $-2.9 e-011$ & $3.8 \mathrm{e}-006$ & $-7.3 e-011$ & $-4.1 e-009$ \\
\hline & $81: 08)$ & $(0.0)$ & $(-0.0)$ & $(-1.1)$ & $(-1.0)$ & $(3.3 * * *)$ & $(-1.3)$ & $(-1.0)$ \\
\hline & (81:09- & -0.08 & 21.8 & $(-0.0)$ & $-2.0 e-010$ & $-1.0 e-005$ & $-9.6 e-011$ & $-1.9 e-008$ \\
\hline & $87: 11)$ & $(-1.3)$ & (1.5) & $-1.8 e-007$ & $(-0.5)$ & $(-1.2)$ & $(-0.3)$ & $(-0.5)$ \\
\hline & (87:12- & -0.4 & 94.0 & $1.6 e-006$ & $-3.0 e-008$ & $-3.5 e-005$ & $-1.1 e-007$ & $1.8 \mathrm{e}-007$ \\
\hline & 91:03) & $(-1.9 *)$ & $\left(2.1^{* *}\right)$ & $(0.4)$ & $\left(-3.8^{* * *}\right)$ & $(-1.1)$ & $\left(-2.8^{* * *}\right)$ & $\left(4.7^{* * *}\right)$ \\
\hline & (91:04- & 0.2 & -59.7 & $-4.4 e-005$ & $2.7 e-009$ & $6.9 e-005$ & $-3.9 e-009$ & $2.1 \mathrm{e}-007$ \\
\hline & 98:12) & $\left(1.8^{*}\right)$ & $\left(-1.8^{*}\right)$ & $\left(-4.0^{* * *}\right)$ & $(3.5 * * *)$ & $(1.0)$ & $(-0.5)$ & $(3.5 * * *)$ \\
\hline
\end{tabular}


Table 6 (cont.): Parameter Estimation in Segmented Market Case (Subperiods)

\begin{tabular}{|c|c|c|c|c|c|c|c|c|}
\hline $\begin{array}{l}\text { Countr } \\
\mathrm{y}\end{array}$ & Periods & Constant & $\operatorname{VAR}\left(\mathrm{R}_{\mathrm{i}}\right)$ & $\operatorname{CoV}\left(\mathrm{R}_{\mathrm{i}}, 1 / \mathrm{I}_{\mathrm{i}}\right)$ & $\operatorname{cov}^{2}\left(R_{i}, 1 / I_{i}\right)$ & $\operatorname{Cov}\left(R_{i}, 1 / I_{i}^{*}\right)$ & $\operatorname{COV}^{2}\left(R_{i}, 1 / I_{i}^{*}\right)$ & $\begin{array}{l}{\left[\operatorname{COV}\left(\mathrm{R}_{\mathrm{i}}, 1 / \mathrm{I}_{\mathrm{i}}\right)^{*}\right.} \\
\operatorname{COV}\left(\mathrm{R}_{\mathrm{i}}, 1 / \mathrm{I}_{\mathrm{i}}{ }^{*}\right]\end{array}$ \\
\hline \multirow{5}{*}{$\begin{array}{l}\text { Germa } \\
\text { ny }\end{array}$} & $\begin{array}{c}73: 02- \\
81: 02)\end{array}$ & $\begin{array}{l}0.02 \\
(1.0)\end{array}$ & $\begin{array}{l}-10.5 \\
(-1.5)\end{array}$ & $\begin{array}{c}-5.9 e-005 \\
(-1.1)\end{array}$ & $\begin{array}{c}2.0 \mathrm{e}-007 \\
(0.5)\end{array}$ & $\begin{array}{c}6.3 \mathrm{e}-006 \\
(0.1)\end{array}$ & $\begin{array}{c}1.0 \mathrm{e}-008 \\
(0.8)\end{array}$ & $\begin{array}{c}1.2 \mathrm{e}-007 \\
(0.8)\end{array}$ \\
\hline & (81:03- & 0.07 & -21.5 & $-1.9 e-004$ & $-6.2 e-007$ & $-1.3 e-006$ & $-1.6 e-007$ & $-2.5 e-008$ \\
\hline & $87: 11)$ & $\left(9.2^{* * *}\right)$ & $\left(-6.7^{* * *}\right)$ & $\left(-5.1^{* * *}\right)$ & $\left(-2.6^{* * *}\right)$ & $(-0.1)$ & $(-2.9 * * *)$ & $(-0.1)$ \\
\hline & (87:12- & 0.01 & -1.4 & $2.5 e-005$ & $1.3 e-008$ & $1.5 e-005$ & $1.3 e-009$ & $8.5 e-009$ \\
\hline & $98: 12)$ & $\left(1.8^{*}\right)$ & $(-0.7)$ & (1.3) & $(2.0 * *)$ & $\left(2.3^{* *}\right)$ & (1.2) & $\left(1.6^{*}\right)$ \\
\hline \multirow{8}{*}{ Italy } & (73:02- & -0.9 & 36.6 & $-8.4 e-004$ & $-2.0 e-007$ & $-4.3 e-003$ & $-6.7 e-006$ & $-2.2 e-006$ \\
\hline & $81: 11)$ & $(-1.4)$ & $(0.4)$ & $\left(-3.1^{* * *}\right)$ & $\left(-3.0^{* * *}\right)$ & $(-3.0 * * *)$ & $(-2.9 * * *)$ & $(-2.9 * * *)$ \\
\hline & (81:12- & 1.1 & -118.4 & $7.4 e-005$ & $-1.6 e-008$ & $1.7 e-003$ & $1.7 e-006$ & $4.8 \mathrm{e}-007$ \\
\hline & $86: 06)$ & $(3.0 * * *)$ & $(-5.1 * * *)$ & (0.9) & $(-1.9 *)$ & (1.3) & $(1.2)$ & $\left(1.7^{*}\right)$ \\
\hline & (86:07- & 0.08 & -14.0 & $5.1 \mathrm{e}-005$ & $3.4 \mathrm{e}-008$ & $2.1 \mathrm{e}-005$ & $-7.3 e-009$ & $2.9 e-007$ \\
\hline & $91: 06)$ & (0.5) & $(-0.5)$ & $(6.3 * * *)$ & $(5.7 * * *)$ & (0.7) & $\left(-3.1^{* * *}\right)$ & $(6.0 * * *)$ \\
\hline & (91:07- & -5.1 & 776.9 & $-1.5 e-004$ & $-4.8 e-009$ & $-4.6 e-003$ & $-6.9 e-006$ & $-5.7 e-007$ \\
\hline & $98: 12)$ & $(-1.2)$ & $(1.2)$ & $(-0.5)$ & $(-0.07)$ & $(-1.4)$ & $(-1.4)$ & $(-0.6)$ \\
\hline \multirow{7}{*}{ Japan } & $\begin{array}{l}\text { (73:02- } \\
79: 08)\end{array}$ & $\begin{array}{c}3.2 \mathrm{e}-003 \\
(0.6)\end{array}$ & $\begin{array}{c}-1.5 \\
(-0.8)\end{array}$ & $\begin{array}{c}-7.3 e-006 \\
(-0.2)\end{array}$ & $\begin{array}{c}2.9 \mathrm{e}-008 \\
\left(1.8^{*}\right)\end{array}$ & $\begin{array}{c}1.5 e-006 \\
(0.3)\end{array}$ & $\begin{array}{c}1.3 e-009 \\
(1.0)\end{array}$ & $\begin{array}{c}5.7 e-009 \\
(0.4)\end{array}$ \\
\hline & (79:08- & 0.01 & -0.3 & $9.5 e-006$ & $-5.4 e-010$ & $4.1 e-006$ & $-2.2 e-011$ & $-4.1 e-010$ \\
\hline & $86: 03)$ & $(2.6 * * *)$ & $(-0.4)$ & $(6.0 * * *)$ & $(-0.5)$ & $(3.0 * * *)$ & $(-0.6)$ & $(-1.0)$ \\
\hline & (86:04- & 0.01 & 0.9 & $-7.7 e-005$ & $4.5 e-008$ & $-1.4 e-00$ & 7.2e-009 & $6.3 e-008$ \\
\hline & $90: 01)$ & (0.8) & (0.3) & $(-4.9 * * *)$ & $\left(3.4^{* * *}\right)$ & $(-1.1)$ & $\left(3.5^{* * *}\right)$ & $(4.7 * * *)$ \\
\hline & (90:02- & -0.02 & 1.8 & $-7.4 e-006$ & $-3.6 e-010$ & $-1.2 e-007$ & $-6.6 e-012$ & $8.8 e-010$ \\
\hline & $98: 12)$ & $(-1.6)$ & $\left(1.8^{*}\right)$ & $(-1.0)$ & $(-0.7)$ & $(-0.0)$ & $(-0.2)$ & $(1.5)$ \\
\hline \multirow{8}{*}{ UK } & (73:02- & -138.9 & 10.4 & 0.97 & -0.0007 & 0.9 & -0.001 & -0.002 \\
\hline & 75:09) & $(-0.5)$ & $(5.0 * * *)$ & $\left(1.7^{*}\right)$ & $\left(-1.6^{*}\right)$ & $(1.2)$ & $\left(-1.7^{*}\right)$ & $\left(-1.7^{*}\right)$ \\
\hline & (75:10- & -46.6 & 0.7 & -0.2 & -0.0001 & 0.03 & -0.000001 & 0.00006 \\
\hline & $87: 11)$ & $(-0.7)$ & (0.5) & $(-0.6)$ & $(-0.6)$ & $(0.8)$ & $(-0.8)$ & $(0.8)$ \\
\hline & (87:12- & 516.2 & -2.2 & 5.8 & 0.009 & 2.0 & -0.0004 & 0.003 \\
\hline & $92: 11)$ & $(0.2)$ & $\left(-1.6^{*}\right)$ & (0.7) & (1.6) & (1.4) & $(-1.5)$ & $(0.8)$ \\
\hline & (92:12- & 593.1 & 1.6 & 2.4 & 0.002 & -0.2 & -0.0002 & -0.001 \\
\hline & $98: 12)$ & $(0.8)$ & $(0.2)$ & (1.0) & (1.1) & $(-0.3)$ & $\left(-3.1^{* * *}\right)$ & $(-0.9)$ \\
\hline \multirow{8}{*}{$\begin{array}{l}\text { Switzer } \\
\text { land }\end{array}$} & (73:02- & $8.9 e-003$ & -3.8 & $2.1 \mathrm{e}-006$ & $-9.0 e-010$ & $-1.5 e-007$ & $1.1 \mathrm{e}-012$ & $-2.4 e-009$ \\
\hline & 83:09) & (1.0) & $(-1.1)$ & $\left(2.2^{* *}\right)$ & $(-8.9 * * *)$ & $(-9.3 * * *)$ & $(0.0)$ & $(-8.9 * * *)$ \\
\hline & (83:10- & -0.04 & 19.2 & $6.3 e-006$ & $5.9 e-011$ & $-7.7 e-008$ & $-8.4 e-014$ & $-3.7 e-013$ \\
\hline & $87: 07)$ & $(-1.4)$ & $\left(2.0^{* *}\right)$ & $\left(2.5^{* * *}\right)$ & $\left(4.1^{* * *}\right)$ & $(-1.0)$ & $(0.0)$ & $(0.0)$ \\
\hline & (87:08- & 0.05 & -11.9 & $-7.8 e-007$ & $-3.2 e-011$ & $1.3 e-006$ & $4.6 e-012$ & $2.1 \mathrm{e}-010$ \\
\hline & 91:05) & $(3.9 * * *)$ & $(-5.4 * * *)$ & $(-0.1)$ & $(-0.1)$ & $\left(2.0^{* *}\right)$ & $\left(2.2^{* *}\right)$ & $(1.6)$ \\
\hline & (91:06- & 0.02 & -1.9 & $-1.1 e-006$ & $3.7 e-010$ & $9.6 e-008$ & $-4.3 e-013$ & $9.8 \mathrm{e}-010$ \\
\hline & $98: 12)$ & $\left(2.2^{* *}\right)$ & $(-0.6)$ & $(-0.7)$ & $(1.0)$ & $(0.8)$ & $(0.0)$ & $(1.0)$ \\
\hline
\end{tabular}

Statistical significance at the $10 \%, 5 \%$, and $1 \%$ level is indicated by $*, * *, * *$ respectively, $\mathrm{t}$ values are in parentheses

Towards the objective of comparing two models, J-tests are implemented for both full and sub-period samples. Table 7 shows the results of these tests. First part (I) of Table 7 reports the regression results when the estimated value of national equity return by segmented market model is added as a regressor to the integrated market model. 
International Asset Pricing, Currency Risk and Integration of Markets

Table 7: Comparing integrated market model with segmented market model

I. This part of the table reports the results of regression where the fitted value of $Y$ is estimated by segmented market model.

PANEL A: Full Period (1973:02-1998:12)

\begin{tabular}{|c|c|c|c|c|c|c|}
\hline \multicolumn{2}{|l|}{ Country } & Constant & $\operatorname{COV}\left(R_{i}, R_{M}\right)$ & $\operatorname{COV}\left(R_{M}, 1 / I_{i}\right)$ & $E\left(1 / I_{i}\right)$ & Estimated $\mathrm{Y}$ \\
\hline \multicolumn{2}{|l|}{ US } & $\begin{array}{c}4.9 e-004 \\
(0.2)\end{array}$ & $\begin{array}{c}0.1 \\
(0.3) \\
\end{array}$ & $\begin{array}{c}-1.9 e-007 \\
(-0.7) \\
\end{array}$ & $\begin{array}{c}-1.2 \mathrm{e}-008 \\
\left(-2.1^{* *}\right) \\
\end{array}$ & $\begin{array}{c}0.97 \\
\left(5.6^{* * *}\right) \\
\end{array}$ \\
\hline \multicolumn{2}{|l|}{ France } & $\begin{array}{l}0.001 \\
(0.2)\end{array}$ & $\begin{array}{c}2.1 \\
(0.5)\end{array}$ & $\begin{array}{c}0.000006 \\
(1.4)\end{array}$ & $\begin{array}{c}-0.00000005 \\
(-0.6)\end{array}$ & $\begin{array}{l}0.77 \\
(1.2)\end{array}$ \\
\hline \multicolumn{2}{|c|}{ Germany } & $\begin{array}{c}0.001 \\
(0.4) \\
\end{array}$ & $\begin{array}{c}-5.0 \\
\left(-4.0^{* * *}\right) \\
\end{array}$ & $\begin{array}{c}(1.4) \\
-0.00003 \\
\end{array}$ & $\begin{array}{c}0.0000001 \\
(1.4)\end{array}$ & $\begin{array}{c}0.93 \\
\left(2.6^{* * *}\right) \\
\end{array}$ \\
\hline \multicolumn{2}{|l|}{ Italy } & $\begin{array}{c}-2.5 e-003 \\
(-0.4) \\
\end{array}$ & $\begin{array}{l}11.0 \\
(1.4) \\
\end{array}$ & $\begin{array}{c}3.7 e-006 \\
(1.1) \\
\end{array}$ & $\begin{array}{c}-7.1 \mathrm{e}-008 \\
\left(-4.2^{* * *}\right) \\
\end{array}$ & $\begin{array}{c}0.88 \\
(2.0 * *) \\
\end{array}$ \\
\hline \multicolumn{2}{|l|}{ Japan } & $\begin{array}{c}-0.0007 \\
(-0.2)\end{array}$ & $\begin{array}{c}1.1 \\
(0.8)\end{array}$ & $\begin{array}{c}0.000008 \\
(0.6)\end{array}$ & $\begin{array}{c}0.0000002 \\
(0.6)\end{array}$ & $\begin{array}{c}0.93 \\
(3.6 * * *)\end{array}$ \\
\hline \multicolumn{2}{|l|}{ UK } & $\begin{array}{c}-4.1 e-004 \\
(-0.1) \\
\end{array}$ & $\begin{array}{c}0.7 \\
(0.2) \\
\end{array}$ & $\begin{array}{c}4.8 \mathrm{e}-006 \\
(1.2)\end{array}$ & $\begin{array}{l}-6.2 \mathrm{e}-008 \\
\left(-8.0^{* * *}\right) \\
\end{array}$ & $\begin{array}{c}0.98 \\
\left(3.7^{* * *}\right) \\
\end{array}$ \\
\hline \multicolumn{2}{|c|}{ Switzerland } & $\begin{array}{c}0.0001 \\
(0.3) \\
\end{array}$ & $\begin{array}{l}-6.4 \\
(-1.3) \\
\end{array}$ & $\begin{array}{c}-0.00002 \\
(-0.1)\end{array}$ & $\begin{array}{c}0.0000002 \\
\left(1.9^{*}\right)\end{array}$ & $\begin{array}{c}0.93 \\
\left(2.9^{* * *}\right) \\
\end{array}$ \\
\hline \multicolumn{7}{|c|}{ PANEL B:SUB-PERIODS } \\
\hline $\begin{array}{l}\text { Countr } \\
\mathrm{y}\end{array}$ & Periods & Constant & $\operatorname{COV}\left(\mathbf{R}_{\mathrm{i}}, \mathbf{R}_{\mathrm{M}}\right)$ & $\operatorname{cov}\left(R_{M}, 1 / I_{i}\right)$ & $E\left(1 / I_{i}\right)$ & Estimated Y \\
\hline US & \begin{tabular}{|l|}
$(73: 02-75: 03)$ \\
$(75: 04-87: 11)$ \\
$(87: 12-90: 06)$ \\
$(90: 07-98: 12)$ \\
\end{tabular} & \begin{tabular}{|c|}
$-0.005(-0.7)$ \\
$-0.0003(-0.1)$ \\
$-1.0 \mathrm{e}-00(-0.2)$ \\
$0.002(0.3)$ \\
\end{tabular} & $\begin{array}{c}9.1(1.4) \\
-6.1(-1.0) \\
0.2(1.3) \\
-4.0(-0.4) \\
\end{array}$ & $\begin{array}{c}0.0000002(0.3) \\
0.0000002(0.3) \\
1.7 e-007(0.5) \\
-0.0000008(-1.4) \\
\end{array}$ & $\begin{array}{l}-0.000003(-2.2) \\
-0.0000003(-0.3) \\
-5.2 \mathrm{e}-009(-1.6) \\
-0.0000001(-0.9) \\
\end{array}$ & $\begin{array}{c}0.95\left(11.5^{* * *}\right) \\
0.99\left(4.5^{* * *}\right) \\
1.1\left(6.7^{* * *}\right) \\
0.89(2.9 * * *) \\
\end{array}$ \\
\hline France & \begin{tabular}{|l|}
$(73: 02-81: 08)$ \\
$(81: 09-87: 11)$ \\
$(87: 12-91: 03)$ \\
$(91: 04-98: 12)$ \\
\end{tabular} & $\begin{array}{c}0.001(0.9) \\
0.0008(0.1) \\
-0.005(-0.4) \\
-0.007\left(-1.8^{*}\right) \\
\end{array}$ & \begin{tabular}{|c|}
$-2.5(-0.3)$ \\
$-3.8(-1.3)$ \\
$14.4(1.1)$ \\
$30.8\left(2.6^{* * *}\right)$ \\
\end{tabular} & $\begin{array}{c}0.00003(2.9 * * *) \\
-0.000005(-1.3) \\
-0.000001(-0.1) \\
0.00001(0.3)\end{array}$ & $\begin{array}{c}-0.0000001\left(-4.2^{* * *}\right) \\
0.0000001\left(2.9^{* * *}\right) \\
0.000001\left(4.2^{* * *}\right) \\
0.0000003(2.3 * *)\end{array}$ & $\begin{array}{c}1.1\left(3.6^{* * *}\right) \\
1.1\left(2.1^{* *}\right) \\
1.0\left(5.4^{* * *}\right) \\
0.96\left(4.7^{* * *}\right) \\
\end{array}$ \\
\hline $\begin{array}{l}\text { Germa } \\
\text { ny }\end{array}$ & \begin{tabular}{|l|}
$(73: 02-81: 02)$ \\
$(81: 03-87: 11)$ \\
$(87: 12-98: 12)$ \\
\end{tabular} & $\begin{array}{c}0.0009(0.3) \\
0.001(0.2) \\
0.005(0.8) \\
\end{array}$ & \begin{tabular}{|c|}
$-1.3(-0.2)$ \\
$-4.8(-0.9)$ \\
$-5.2\left(-3.6^{* * *}\right)$ \\
\end{tabular} & $\begin{array}{c}0.00002(0.3) \\
-0.00006(-1.2) \\
-0.000004(-0.1) \\
\end{array}$ & $\begin{array}{c}0.0000004(2.1) \\
0.0000002\left(6.6^{* * *}\right) \\
-0.0000001(-0.9) \\
\end{array}$ & $\begin{array}{c}0.98\left(2.4^{* *}\right) \\
1.00\left(14.3^{* * *}\right) \\
0.71\left(2.3^{* *}\right) \\
\end{array}$ \\
\hline Italy & $\begin{array}{l}(73: 02-81: 11) \\
(81: 12-86: 06) \\
(86: 07-91: 06) \\
(91: 07-98: 12)\end{array}$ & $\begin{array}{c}-0.002(-0.1) \\
0.013(0.7) \\
-2.6 e-003(-0.4) \\
-0.026(-1.1) \\
\end{array}$ & $\begin{array}{c}3.0(0.2) \\
-26.9(-1.6) \\
11.7(0.9) \\
52.4\left(2.0^{* *}\right) \\
\end{array}$ & $\begin{array}{c}0.0000005(0.1) \\
-4.9 e-006(-0.9) \\
2.3 e-006(0.5) \\
9.2 e-006(1.3)\end{array}$ & $\begin{array}{c}0.0000004(0.6) \\
-5.1 \mathrm{e}-008\left(-2.2^{* *}\right) \\
-6.3 \mathrm{e}-008\left(-7.8^{* * *}\right) \\
-1.4 \mathrm{e}-007\left(-6.8^{* * *}\right)\end{array}$ & $\begin{array}{c}0.99\left(3.4^{* * *}\right) \\
1.04\left(3.9^{* * *}\right) \\
0.85\left(2.5^{* *}\right) \\
0.91\left(1.8^{*}\right) \\
\end{array}$ \\
\hline Japan & $\begin{array}{l}(73: 02-79: 08) \\
(79: 09-86: 03) \\
(86: 04-90: 01) \\
(90: 02-98: 12) \\
\end{array}$ & $\begin{array}{c}0.001(0.3) \\
0.0003(0.1) \\
-0.009(-0.7) \\
-0.003(-0.5) \\
\end{array}$ & $\begin{array}{c}-4.2\left(-1.8^{*}\right) \\
-4.4(-1.3) \\
2.6(0.6) \\
2.5\left(2.4^{* *}\right) \\
\end{array}$ & $\begin{array}{c}0.0001(1.4) \\
0.000005(0.5) \\
0.00006\left(1.7^{*}\right) \\
-0.00001(-0.3) \\
\end{array}$ & $\begin{array}{c}-0.00000003(-0.0) \\
0.0000003(1.0) \\
0.000004\left(3.8^{* * *}\right) \\
-0.0000003(-0.6)\end{array}$ & $\begin{array}{c}1.3\left(3.6^{* * *}\right) \\
1.0\left(16.1^{* * *}\right) \\
1.2\left(8.0^{* * *}\right) \\
0.9\left(4.0^{* * *}\right) \\
\end{array}$ \\
\hline UK & \begin{tabular}{l|}
$(73: 02-75: 09)$ \\
$(75: 10-87: 11)$ \\
$(87: 12-92: 11)$ \\
$(92: 12-98: 12)$
\end{tabular} & $\begin{array}{c}-0.02\left(-1.8^{*}\right) \\
-0.003(-0.4) \\
-0.005(-0.6) \\
1.0 e-003(0.3)\end{array}$ & \begin{tabular}{|c|}
$7.2\left(4.8^{* * *}\right)$ \\
$6.2\left(1.8^{*}\right)$ \\
$-1.2(-0.8)$ \\
$-14.8\left(-3.5^{* * *}\right)$ \\
\end{tabular} & \begin{tabular}{|c|}
$0.00008(0.6)$ \\
$0.0004(0.2)$ \\
$0.001\left(1.8^{*}\right)$ \\
$-9.1 \mathrm{e}-006\left(-3.3^{* * *}\right)$ \\
\end{tabular} & $\begin{array}{c}0.00002(0.8) \\
-0.000001\left(-2.2^{* *}\right) \\
0.000001\left(1.8^{*}\right) \\
-7.1 \mathrm{e}-008\left(-10.8^{* * *}\right)\end{array}$ & $\begin{array}{c}0.7\left(3.3^{* * *}\right) \\
1.0\left(12.8^{* * *}\right) \\
1.0\left(3.8^{* * *}\right) \\
0.9\left(3.8^{* * *}\right) \\
\end{array}$ \\
\hline $\begin{array}{l}\text { Switzer } \\
\text { land }\end{array}$ & $\begin{array}{l}(73: 02-83: 09) \\
(83: 10-87: 07) \\
(87: 08-91: 05) \\
(91: 06-98: 12)\end{array}$ & $\begin{array}{c}0.001(0.3) \\
-0.0002(-0.0) \\
-0.002(-0.3) \\
6.1 e-003(1.5)\end{array}$ & \begin{tabular}{|c|}
$-9.9\left(-1.7^{*}\right)$ \\
$0.3(0.0)$ \\
$5.3\left(1.7^{*}\right)$ \\
$-43.1\left(-2.5^{* *}\right)$ \\
\end{tabular} & $\begin{array}{c}-0.00002(-0.9) \\
0.00001(0.3) \\
0.00001(1.0) \\
-1.4 \mathrm{e}-004\left(-2.5^{* *}\right)\end{array}$ & $\begin{array}{c}-4.0 \mathrm{e}-009(-0.1) \\
-3.0 \mathrm{e}-008(-0.2) \\
-0.0000002(-0.3) \\
2.2 \mathrm{e}-007\left(5.5^{* * *}\right)\end{array}$ & $\begin{array}{l}0.9(9.8 * * *) \\
1.0(9.0 * * *) \\
1.1(4.9 * * *) \\
0.8\left(5.5^{* * *}\right)\end{array}$ \\
\hline
\end{tabular}


Table 7 (cont.): Comparing integrated market model with segmented market model

\begin{tabular}{|c|c|c|c|c|c|c|c|c|}
\hline \multicolumn{9}{|c|}{ PANEL B:SUB-PERIODS } \\
\hline Count & Periods & \multicolumn{2}{|c|}{ Constant } & $\operatorname{cov}\left(R_{i}, R_{M}\right)$ & $\operatorname{cov}\left(R_{M}, 1 / I_{i}\right)$ & \multicolumn{2}{|c|}{$E\left(1 / I_{i}\right)$} & Estimated $Y$ \\
\hline US & \begin{tabular}{|l|}
$(73: 02-75: 03)$ \\
$(75: 04-87: 11)$
\end{tabular} & \begin{tabular}{r|r} 
3) & -0.0 \\
1) & -0.00 \\
5) & $-1.0 \mathrm{e}$ \\
2) & 0.0
\end{tabular} & $\begin{array}{l}05(-0.7) \\
03(-0.1) \\
-00(-0.2) \\
02(0.3)\end{array}$ & $\begin{array}{c}9.1(1.4) \\
-6.1(-1.0) \\
0.2(1.3) \\
-4.0(-0.4)\end{array}$ & $\begin{array}{c}1.7 e-007(0.5) \\
-0.0000008(-1.4)\end{array}$ & $\begin{array}{r}-0.00000 \\
-0.000000 \\
-5.2 \mathrm{e}-000 \\
-0.000000\end{array}$ & $\begin{array}{l}03(-2.2) \\
03(-0.3) \\
09(-1.6) \\
01(-0.9)\end{array}$ & $\begin{array}{c}1.1\left(6.7^{* * *}\right) \\
0.89\left(2.9^{* * *}\right)\end{array}$ \\
\hline France & $\begin{array}{l}(81: 09-87: 11) \\
(87: 12-91: 03)\end{array}$ & \begin{tabular}{c|c} 
3) & 0.0 \\
1) & 0.00 \\
3) & -0.0 \\
2) & -0.00
\end{tabular} & \begin{tabular}{|l|l}
$01(0.9)$ & \\
$08(0.1)$ & \\
$05(-0.4)$ & \\
$7\left(-1.8^{*}\right)$ & 3( \\
\end{tabular} & $\begin{array}{c}-2.5(-0.3) \\
-3.8(-1.3) \\
14.4(1.1) \\
30.8\left(2.6^{* * *}\right) \\
\end{array}$ & $\begin{array}{l}-0.000005(-1.3) \\
-0.000001(-0.1)\end{array}$ & \begin{tabular}{l|c}
$* *)$ & -0.0000001 \\
3) & 0.0000001 \\
1) & 0.000001 \\
) & 0.0000003 \\
\end{tabular} & \begin{tabular}{l|l}
$1\left(-4.2^{* * *}\right)$ & \\
$1\left(2.9^{* * *}\right)$ & \\
$\left(4.2^{* * *}\right)$ & \\
$3\left(2.3^{* *}\right)$ & 0 \\
\end{tabular} & $\begin{array}{c}1.1\left(3.6^{* * *}\right) \\
1.1\left(2.1^{* *}\right) \\
1.0\left(5.4^{* * *}\right) \\
0.96\left(4.7^{* * *}\right) \\
\end{array}$ \\
\hline $\begin{array}{l}\text { Germa } \\
\text { ny }\end{array}$ & $\begin{array}{l}(73: 02-81: 02) \\
(81: 03-87: 11) \\
(87: 12-98: 12)\end{array}$ & $\begin{array}{r}0.00 \\
0.0 \\
0.0 \\
\end{array}$ & $\begin{array}{l}09(0.3) \\
01(0.2) \\
05(0.8)\end{array}$ & \begin{tabular}{|c|}
$-1.3(-0.2)$ \\
$-4.8(-0.9)$ \\
$-5.2\left(-3.6^{* * *}\right)$ \\
\end{tabular} & $\begin{array}{r}0.00002(0.3) \\
-0.00006(-1.2) \\
-0.000004(-0.1 \\
\end{array}$ & $\begin{array}{r}0.000000 \\
0.0000002 \\
-0.000000 \\
\end{array}$ & \begin{tabular}{l|r}
$04(2.1)$ & \\
$2\left(6.6^{* * *}\right)$ & 1. \\
$01(-0.9)$ & 0 \\
\end{tabular} & $\begin{array}{c}0.98\left(2.4^{* *}\right) \\
1.00\left(14.3^{* * *}\right) \\
0.71\left(2.3^{* *}\right)\end{array}$ \\
\hline Italy & $\begin{array}{l}(73: 02-81: 1 \\
(81: 12-86: 0 \\
(86: 07-91: 0 \\
(91: 07-98: 1 \\
\end{array}$ & \begin{tabular}{r|r} 
1) & -0.0 \\
5) & 0.0 \\
6) & $-2.6 \mathrm{e}$ \\
2) & -0.0 \\
\end{tabular} & \begin{tabular}{l|l}
$2(-0.1)$ & \\
$13(0.7)$ & - \\
$003(-0.4)$ & \\
$26(-1.1)$ & 5 \\
\end{tabular} & $\begin{array}{c}3.0(0.2) \\
-26.9(-1.6) \\
11.7(0.9) \\
52.4\left(2.0^{* *}\right) \\
\end{array}$ & $\begin{array}{r}0.0000005(0.1 \\
-4.9 \mathrm{e}-006(-0.9 \\
2.3 \mathrm{e}-006(0.5) \\
9.2 \mathrm{e}-006(1.3) \\
\end{array}$ & $\begin{array}{r}0.000000 \\
-5.1 \mathrm{e}-008 \\
-6.3 \mathrm{e}-008 \\
-1.4 \mathrm{e}-007 \\
\end{array}$ & $\begin{array}{l}04(0.6) \\
\left(-2.2^{* *}\right) \\
\left(-7.8^{* * *}\right) \\
\left(-6.8^{* * *}\right) \\
\end{array}$ & $\begin{array}{l}0.99\left(3.4^{* * *}\right) \\
1.04\left(3.9^{* * *}\right) \\
0.85\left(2.5^{* *}\right) \\
0.91\left(1.8^{*}\right) \\
\end{array}$ \\
\hline Japan & \begin{tabular}{|l|}
$73: 02-79: 0$ \\
$(79: 09-86: 0$ \\
$(86: 04-90: 0$ \\
$(90: 02-98: 1$
\end{tabular} & $\begin{array}{c}0.0 \\
0.00 \\
-0.0 \\
-0.0 \\
\end{array}$ & $\begin{array}{l}1(0.3) \\
03(0.1) \\
09(-0.7) \\
03(-0.5)\end{array}$ & $\begin{array}{c}-4.2\left(-1.8^{*}\right) \\
-4.4(-1.3) \\
2.6(0.6) \\
2.5\left(2.4^{* *}\right)\end{array}$ & $\begin{array}{c}0.0001(1.4) \\
0.000005(0.5) \\
0.00006\left(1.7^{*}\right. \\
-0.00001(-0.3\end{array}$ & $\begin{array}{r}-0.000000 \\
0.000000 \\
0.000004 \\
-0.000000\end{array}$ & $\begin{array}{l}003(-0.0) \\
03(1.0) \\
\left(3.8^{* * *}\right) \\
03(-0.6)\end{array}$ & $\begin{array}{c}1.3\left(3.6^{* * *}\right) \\
1.0\left(16.1^{* * *}\right) \\
1.2\left(8.0^{* * *}\right) \\
0.9\left(4.0^{* * *}\right)\end{array}$ \\
\hline UK & $\begin{array}{l}(73: 02-75: 0 \\
(75: 10-87: 1 \\
(87: 12-92: 1 \\
(92: 12-98: 1\end{array}$ & $\begin{array}{l}-0.0 \\
-0.0 \\
-0.0 \\
1.0 \mathrm{e}\end{array}$ & \begin{tabular}{l|r}
$2\left(-1.8^{*}\right)$ & 7 \\
$03(-0.4)$ & \\
$05(-0.6)$ & \\
$003(0.3)$ & -1 \\
\end{tabular} & $\begin{array}{c}7.2\left(4.8^{* * *}\right) \\
6.2\left(1.8^{*}\right) \\
-1.2(-0.8) \\
-14.8\left(-3.5^{* * *}\right)\end{array}$ & $\begin{array}{r}0.00008(0.6) \\
0.0004(0.2) \\
0.001\left(1.8^{*}\right) \\
-9.1 \mathrm{e}-006\left(-3.3^{*}\right.\end{array}$ & \begin{tabular}{l|r} 
& 0.00002 \\
& -0.000001 \\
$* *)$ & 0.000001 \\
$-7.1 \mathrm{e}-008(-$
\end{tabular} & $\begin{array}{l}2(0.8) \\
1\left(-2.2^{* *}\right) \\
1\left(1.8^{*}\right) \\
\left(-10.8^{* * *}\right)\end{array}$ & $\begin{array}{c}0.7\left(3.3^{* * *}\right) \\
1.0\left(12.8^{* * *}\right) \\
1.0\left(3.8^{* * *}\right) \\
0.9\left(3.8^{* * *}\right)\end{array}$ \\
\hline $\begin{array}{l}\text { Switzer } \\
\text { land }\end{array}$ & $\begin{array}{l}73: 02-83: 0 \\
(83: 10-87: 0 \\
(87: 08-91: 0 \\
(91: 06-98: 1\end{array}$ & \begin{tabular}{l|r} 
9) & 0.0 \\
7) & -0.00 \\
5) & -0.0 \\
2) & $6.1 \mathrm{e}$
\end{tabular} & \begin{tabular}{l|l}
$01(0.3)$ & - \\
$02(-0.0)$ & \\
$02(-0.3)$ & \\
$003(1.5)$ & -4 \\
\end{tabular} & $\begin{array}{c}-9.9\left(-1.7^{*}\right) \\
0.3(0.0) \\
5.3\left(1.7^{*}\right) \\
-43.1\left(-2.5^{* *}\right)\end{array}$ & $\begin{array}{r}-0.00002(-0.9 \\
0.00001(0.3) \\
0.00001(1.0) \\
-1.4 \mathrm{e}-004\left(-2.5^{*}\right.\end{array}$ & \begin{tabular}{l|l}
) & $-4.0 \mathrm{e}-00$ \\
)$^{*}$ & $-3.0 \mathrm{e}-00$ \\
& -0.00000 \\
& $2.2 \mathrm{e}-007($
\end{tabular} & $\begin{array}{l}09(-0.1) \\
08(-0.2) \\
02(-0.3) \\
\left(5.5^{* * *}\right)\end{array}$ & $\begin{array}{l}0.9\left(9.8^{* * *}\right) \\
1.0\left(9.0^{* * *}\right) \\
1.1\left(4.9^{* * *}\right) \\
0.8\left(5.5^{* * *}\right)\end{array}$ \\
\hline Th & S & & & & & & & \\
\hline \begin{tabular}{|l} 
PANE \\
\end{tabular} & & & & & & & & \\
\hline $\begin{array}{l}\text { Countr } \\
\mathrm{y}\end{array}$ & Constant & $\operatorname{VAR}\left(R_{i}\right)$ & $\operatorname{COV}\left(\mathrm{R}_{\mathrm{i}}, 1 / \mathrm{I}_{\mathrm{i}}\right)$ & $\operatorname{cov}^{2}\left(R_{i}, 1 / I_{i}\right)$ & $\operatorname{cov}\left(R_{i}, 1 / I_{i}^{*}\right)$ & $\operatorname{Cov}^{2}\left(R_{i}, 1 / I_{i}^{*}\right)$ & $\begin{array}{l}{\left[\operatorname{COV}\left(\mathrm{R}_{\mathrm{i}}, 1 / \mathrm{I}_{\mathrm{i}}\right)^{*}\right.} \\
\operatorname{COV}\left(\mathrm{R}_{\mathrm{i}}, 1 / \mathrm{I}_{\mathrm{i}}\right]\end{array}$ & ] ${ }_{\text {] }}^{*}$ Estimated Y \\
\hline US & $\begin{array}{c}-6.0 \mathrm{e}-003 \\
(-0.6)\end{array}$ & $\begin{array}{c}3.0 \\
\left(1.7^{*}\right)\end{array}$ & $\begin{array}{c}-8.5 \mathrm{e}-006 \\
\left(-2.1^{* *}\right)\end{array}$ & $\begin{array}{l}-2.1 \mathrm{e}-009 \\
(-2.9 * * *)\end{array}$ & $\begin{array}{c}-3.4 \mathrm{e}-006 \\
(-1.4)\end{array}$ & $\begin{array}{c}2.5 \mathrm{e}-010 \\
\left(2.3^{* *}\right)\end{array}$ & $\begin{array}{c}-2.2 \mathrm{e}-009 \\
\left(-2.3^{* *}\right)\end{array}$ & $\begin{array}{c}0.5 \\
(0.6)\end{array}$ \\
\hline France & $\begin{array}{c}2.6 \mathrm{e}-003 \\
(0.1)\end{array}$ & $\begin{array}{c}-1.3 \\
(-0.3)\end{array}$ & $\begin{array}{c}7.4 \mathrm{e}-007 \\
(0.7)\end{array}$ & NA & $\begin{array}{c}2.5 \mathrm{e}-007 \\
(0.7)\end{array}$ & NA & $\begin{array}{c}9.3 \mathrm{e}-011 \\
(1.3)\end{array}$ & $\begin{array}{c}1.4 \\
(1.3)\end{array}$ \\
\hline $\begin{array}{l}\text { Germa } \\
\text { ny }\end{array}$ & $\begin{array}{l}0.01 \\
(1.4)\end{array}$ & $\begin{array}{c}-5.1 \\
(-1.4)\end{array}$ & $\begin{array}{c}-2.6 e-005 \\
(-0.9)\end{array}$ & $\begin{array}{c}-1.2 \mathrm{e}-009 \\
(-0.1)\end{array}$ & $\begin{array}{c}-1.1 \mathrm{e}-006 \\
(-0.1)\end{array}$ & $\begin{array}{c}-9.5 e-010 \\
(-0.8)\end{array}$ & $\begin{array}{c}-2.7 e-009 \\
(-0.4)\end{array}$ & $\begin{array}{c}0.9 \\
(3.9 * * *)\end{array}$ \\
\hline Italy & $\begin{array}{c}0.2 \\
(1.2)\end{array}$ & $\begin{array}{l}-31.4 \\
(-1.2)\end{array}$ & $\begin{array}{c}2.3 e-005 \\
(1.4)\end{array}$ & $\begin{array}{c}8.9 \mathrm{e}-009 \\
\left(2.0^{* *}\right)\end{array}$ & $\begin{array}{c}2.8 \mathrm{e}-005 \\
(0.9)\end{array}$ & $\begin{array}{c}-9.6 e-010 \\
(-0.7)\end{array}$ & $\begin{array}{c}\text { 7.7e-008 } \\
\left(2.0^{* *}\right)\end{array}$ & $\begin{array}{c}0.8 \\
\left(2.9^{* * *}\right)\end{array}$ \\
\hline Japan & $\begin{array}{c}-1.2 \mathrm{e}-003 \\
(-0.3)\end{array}$ & $\begin{array}{c}0.6 \\
\left(1.7^{*}\right)\end{array}$ & $\begin{array}{c}3.7 \mathrm{e}-006 \\
(0.8)\end{array}$ & $\begin{array}{l}-7.5 e-010 \\
\left(-2.7^{* * *}\right)\end{array}$ & $\begin{array}{c}2.5 \mathrm{e}-006 \\
(1.4)\end{array}$ & $\begin{array}{c}-6.6 e-011 \\
\left(-2.0^{* *}\right)\end{array}$ & $\begin{array}{c}-2.0 e-010 \\
(-0.5)\end{array}$ & $\begin{array}{c}0.5 \\
(1.4)\end{array}$ \\
\hline UK & $\begin{array}{c}8.9 \\
(0.5)\end{array}$ & $\begin{array}{c}0.9 \\
(0.9) \\
\end{array}$ & $\begin{array}{l}0.03 \\
(0.5)\end{array}$ & $\begin{array}{c}0.00002 \\
(0.5)\end{array}$ & $\begin{array}{c}-0.004 \\
(-0.4)\end{array}$ & $\begin{array}{c}-0.000001 \\
(-1.2)\end{array}$ & $\begin{array}{c}-0.00001 \\
(-0.6)\end{array}$ & $\begin{array}{c}0.9 \\
(2.0 * *)\end{array}$ \\
\hline \begin{tabular}{|l|} 
Switzerl \\
and
\end{tabular} & $\begin{array}{c}6.2 \mathrm{e}-003 \\
(0.4)\end{array}$ & $\begin{array}{c}-1.9 \\
(-0.5)\end{array}$ & $\begin{array}{c}-4.5 e-007 \\
(-0.5)\end{array}$ & NA & $\begin{array}{c}-0.7 e-009 \\
(-0.3)\end{array}$ & NA & NA & $\begin{array}{c}0.8 \\
(1.4)\end{array}$ \\
\hline
\end{tabular}


International Asset Pricing, Currency Risk and Integration of Markets

Table 7 (cont.): Comparing integrated market model with segmented market model

\begin{tabular}{|c|c|c|c|c|c|c|c|c|c|c|c|c|c|c|}
\hline \multicolumn{15}{|c|}{$\begin{array}{l}\text { II. This part of the table reports the resul } \\
\text { integrated market model. }\end{array}$} \\
\hline \multicolumn{15}{|c|}{ PANEL C: Full Period (1973:02-1998:12) } \\
\hline \begin{tabular}{|l|} 
Countr \\
$\mathrm{y}$
\end{tabular} & Constant & $\operatorname{VAR}\left(R_{\mathrm{i}}\right)$ & \multicolumn{2}{|c|}{$\operatorname{cov}\left(R_{i}, 1 / I_{i}\right)$} & \multicolumn{2}{|c|}{$\operatorname{cov}^{2}\left(R_{i}, 1 / I_{i}\right)$} & \multicolumn{2}{|c|}{$\operatorname{cov}\left(R_{i}, 1 / I_{i}^{*}\right)$} & \multicolumn{2}{|c|}{$\operatorname{cov}^{2}\left(R_{i}, 1 / I_{i}^{*}\right)$} & $\begin{array}{l}{[\mathrm{CO}} \\
\mathrm{CO}\end{array}$ & $\begin{array}{l}\partial V\left(R_{i}, 1 / I_{i}\right)^{*} \\
O V\left(R_{i}, 1 / I_{i}^{*}\right]\end{array}$ & \multicolumn{2}{|c|}{ Estimated Y } \\
\hline US & $\begin{array}{c}-6.0 \mathrm{e}-003 \\
(-0.6)\end{array}$ & $\begin{array}{c}3.0 \\
\left(1.7^{*}\right) \\
\end{array}$ & \multicolumn{2}{|c|}{$\begin{array}{c}-8.5 e-006 \\
\left(-2.1^{* *}\right)\end{array}$} & \multicolumn{2}{|c|}{$\begin{array}{l}-2.1 \mathrm{e}-009 \\
\left(-2.9^{* * *}\right)\end{array}$} & \multicolumn{2}{|c|}{$\begin{array}{c}-3.4 \mathrm{e}-006 \\
(-1.4)\end{array}$} & \multicolumn{2}{|c|}{$\begin{array}{c}2.5 \mathrm{e}-010 \\
\left(2.3^{* *}\right)\end{array}$} & & $\begin{array}{l}2.2 \mathrm{e}-009 \\
\left(-2.3^{* *}\right)\end{array}$ & & $\begin{array}{c}0.5 \\
(0.6)\end{array}$ \\
\hline \begin{tabular}{|l|} 
France \\
\end{tabular} & $\begin{array}{c}2.6 e-003 \\
(0.1)\end{array}$ & $\begin{array}{c}-1.3 \\
(-0.3)\end{array}$ & \multicolumn{2}{|c|}{$\begin{array}{c}7.4 \mathrm{e}-007 \\
(0.7)\end{array}$} & \multicolumn{2}{|c|}{ NA } & \multicolumn{2}{|c|}{$\begin{array}{l}2.5 e-007 \\
(0.7)\end{array}$} & \multicolumn{2}{|r|}{ NA } & & $\begin{array}{c}9.3 e-011 \\
(1.3)\end{array}$ & & $\begin{array}{c}1.4 \\
(1.3) \\
\end{array}$ \\
\hline $\begin{array}{l}\text { Germa } \\
\text { ny }\end{array}$ & $\begin{array}{l}0.01 \\
(1.4)\end{array}$ & $\begin{array}{c}-5.1 \\
(-1.4)\end{array}$ & \multicolumn{2}{|c|}{$\begin{array}{c}-2.6 e-005 \\
(-0.9)\end{array}$} & \multicolumn{2}{|c|}{$\begin{array}{c}-1.2 \mathrm{e}-009 \\
(-0.1)\end{array}$} & \multicolumn{2}{|c|}{$\begin{array}{c}-1.1 \mathrm{e}-006 \\
(-0.1)\end{array}$} & \multicolumn{2}{|c|}{$\begin{array}{c}-9.5 e-010 \\
(-0.8)\end{array}$} & & $\begin{array}{l}2.7 e-009 \\
(-0.4)\end{array}$ & & $\begin{array}{c}0.9 \\
(3.9 * * *)\end{array}$ \\
\hline Italy & $\begin{array}{c}0.2 \\
(1.2)\end{array}$ & $\begin{array}{l}-31.4 \\
(-1.2)\end{array}$ & \multicolumn{2}{|c|}{$\begin{array}{c}2.3 e-005 \\
(1.4)\end{array}$} & \multicolumn{2}{|c|}{$\begin{array}{c}8.9 \mathrm{e}-009 \\
\left(2.0^{* *}\right)\end{array}$} & \multicolumn{2}{|c|}{$\begin{array}{c}2.8 \mathrm{e}-005 \\
(0.9)\end{array}$} & \multicolumn{2}{|c|}{$\begin{array}{c}-9.6 e-010 \\
(-0.7)\end{array}$} & & $\begin{array}{l}7.7 \mathrm{e}-008 \\
\left(2.0^{* *}\right)\end{array}$ & & $\begin{array}{c}0.8 \\
(2.9 * * *)\end{array}$ \\
\hline Japan & $\begin{array}{c}-1.2 \mathrm{e}-003 \\
(-0.3)\end{array}$ & $\begin{array}{c}0.6 \\
\left(1.7^{*}\right)\end{array}$ & $\begin{array}{r}3.7 \mathrm{e}-0 \\
(0.8) \\
\end{array}$ & & $\begin{array}{l}-7.5 \mathrm{e}- \\
\left(-2.7^{*}\right.\end{array}$ & & $\begin{array}{r}2.5 \mathrm{e} \\
(1\end{array}$ & & $\begin{array}{r}-6.6 \\
(-2 \\
\end{array}$ & $\begin{array}{l}6 e-011 \\
2.0 * *)\end{array}$ & & $\begin{array}{l}2.0 \mathrm{e}-010 \\
(-0.5)\end{array}$ & & $\begin{array}{c}0.5 \\
(1.4)\end{array}$ \\
\hline UK & $\begin{array}{c}8.9 \\
(0.5)\end{array}$ & $\begin{array}{c}0.9 \\
(0.9)\end{array}$ & $\begin{array}{l}0.03 \\
(0.5)\end{array}$ & & $\begin{array}{r}0.000 \\
10.5\end{array}$ & & & & $\begin{array}{r}-0.0 \\
(-\end{array}$ & $\begin{array}{l}00001 \\
-1.2)\end{array}$ & & $\begin{array}{c}0.00001 \\
(-0.6)\end{array}$ & & $\begin{array}{c}0.9 \\
\left(2.0^{* *}\right)\end{array}$ \\
\hline $\begin{array}{l}\text { Switzerl } \\
\text { and }\end{array}$ & $\begin{array}{c}6.2 \mathrm{e}-003 \\
(0.4)\end{array}$ & $\begin{array}{c}-1.9 \\
(-0.5)\end{array}$ & $\begin{array}{r}-4.5 e-0 \\
(-0.5)\end{array}$ & & $\mathrm{N} A$ & & $\begin{array}{r}-0.7 e \\
(-0\end{array}$ & $\begin{array}{l}e-009 \\
0.3)\end{array}$ & & NA & & NA & & $\begin{array}{c}0.8 \\
(1.4)\end{array}$ \\
\hline P nitas & & 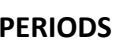 & & & & & & & & & & & & \\
\hline $\begin{array}{l}\text { Countr } \\
\mathrm{y}\end{array}$ & Periods & Constant & $\operatorname{VAR}\left(\mathrm{R}_{\mathrm{i}}\right)$ & $\mathrm{COV}$ & $V\left(R_{i}, 1 / I_{i}\right)$ & $\operatorname{cov}^{2}($ & $\left(R_{i}, 1 / I_{i}\right)$ & $\operatorname{cov}\left(R_{i}\right.$ & $\left.\mathrm{R}_{\mathrm{i}}, 1 / \mathrm{I}_{\mathrm{i}}^{*}\right)$ & $\begin{array}{c}\operatorname{COV}^{2}\left(R_{i}\right. \\
)\end{array}$ & & $\begin{array}{l}{\left[\operatorname{COV}\left(\mathrm{R}_{\mathrm{i}},\right.\right.} \\
\operatorname{Cov}\left(\mathrm{R}_{\mathrm{i}},\right.\end{array}$ & & \begin{tabular}{|c|} 
Estimated \\
$Y$ \\
\end{tabular} \\
\hline US & \begin{tabular}{|c|}
$(73: 02-$ \\
$75: 03)$ \\
$(75: 04-$ \\
$87: 11)$ \\
$(87: 12-$ \\
$90: 06)$ \\
$(90: 07-$ \\
$98: 12)$ \\
\end{tabular} & $\begin{array}{c}-0.05 \\
\left(-8.1^{* * *}\right) \\
-0.02 \\
\left(-2.7^{* * *}\right) \\
5.0 \mathrm{e}-003 \\
(0.9) \\
-0.02 \\
\left(-1.7^{*}\right)\end{array}$ & $\begin{array}{c}0.4 \\
(1.2) \\
-0.4 \\
(-0.4) \\
-3.0 \\
(-0.8) \\
0.3 \\
(0.3)\end{array}$ & & $\begin{array}{l}6 \mathrm{e}-005 \\
\left.5.4^{* * *}\right) \\
.9 \mathrm{e}-005 \\
(-1.4) \\
6 \mathrm{e}-005 \\
\left.2.8^{* * *}\right) \\
.3 \mathrm{e}-005 \\
(-1.6)\end{array}$ & $\begin{array}{c}9.8 \mathrm{e} \\
(6.2 \\
-9.5 € \\
(-1 \\
-4.7 € \\
(-2 . \\
-2.6 € \\
(-2 .\end{array}$ & $\begin{array}{l}-009 \\
* * *) \\
e-009 \\
\left..8^{*}\right) \\
e-009 \\
1 * *) \\
e-008 \\
\left.5^{* *}\right)\end{array}$ & $\begin{array}{r}-3.2 \mathrm{e}- \\
\left(-3.1^{*}\right. \\
-1.2 \mathrm{e}- \\
(-1 . \\
-8.0 \mathrm{e}- \\
(-1 . \\
-5.8 \mathrm{e}- \\
(-0 .\end{array}$ & $\begin{array}{l}2-005 \\
* * *) \\
2-005 \\
.0) \\
2-006 \\
.4) \\
2-006 \\
.4)\end{array}$ & $\begin{array}{r}-3.8 \mathrm{e}-0 \\
\left(-2.6^{* *}\right. \\
-1.9 \mathrm{e}-0 \\
(-0.6) \\
5.0 \mathrm{e}-0 \\
\left(1.7^{*}\right. \\
2.6 \mathrm{e}-0 \\
(0.8)\end{array}$ & $\begin{array}{l}09 \\
* *) \\
09 \\
10 \\
09 \\
09 \\
09\end{array}$ & $\begin{array}{r}-1.0 \mathrm{e}-00 \\
\left(-12.5^{* *}\right. \\
-1.3 \mathrm{e}-00 \\
(-1.5) \\
-4.8 \mathrm{e}-00 \\
(-1.5) \\
-4.6 \mathrm{e}-0 \mathrm{c} \\
\left(-2.2^{* *}\right.\end{array}$ & & $\begin{array}{c}0.6 \\
\left(2.5^{* *}\right) \\
0.9 \\
(1.1) \\
-0.2 \\
(-0.5) \\
1.7 \\
\left(2.4^{* *}\right)\end{array}$ \\
\hline France & \begin{tabular}{|c|}
$(73: 02-$ \\
$81: 08)$ \\
$(81: 09-$ \\
$87: 11)$ \\
$(87: 12-$ \\
$91: 03)$ \\
$(91: 04-$ \\
$98: 12)$
\end{tabular} & $\begin{array}{c}-0.09 \\
\left(-2.3^{* * *}\right) \\
-0.14 \\
\left(-1.7^{*}\right) \\
-0.3 \\
\left(-1.7^{*}\right) \\
0.3 \\
\left(1.8^{*}\right)\end{array}$ & $\begin{array}{c}20.0 \\
\left(2.5^{* *}\right) \\
30.2 \\
\left(1.7^{*}\right) \\
82.6 \\
\left(1.8^{*}\right) \\
-64.2 \\
\left(-1.9^{*}\right)\end{array}$ & & $\begin{array}{l}8 \mathrm{e}-006 \\
(0.5) \\
0 \mathrm{e}-005 \\
(0.8) \\
1 \mathrm{e}-006 \\
(-0.2) \\
6 \mathrm{e}-005 \\
3.5^{* * *)}\end{array}$ & $\begin{array}{r}5.4 \mathrm{e} \\
(1 \\
-7.3 \mathrm{e} \\
(-1 \\
-2.8 \mathrm{e} \\
(-3.2 \\
2.4 \mathrm{e} \\
(3.6\end{array}$ & $\begin{array}{l}-011 \\
.5) \\
e-010 \\
.2) \\
e-008 \\
2 * *) \\
2-009 \\
* * *)\end{array}$ & $\begin{array}{r}7.6 e- \\
(0.6 \\
-3.4 e- \\
(-0 . \\
-3.3 e- \\
(-1 . \\
3.5 e- \\
10.5\end{array}$ & $\begin{array}{l}\text {-007 } \\
.6) \\
2-006 \\
.3) \\
-005 \\
.0) \\
-005 \\
.5)\end{array}$ & $\begin{array}{r}7.9 \mathrm{e}-0 \\
(1.2) \\
-5.9 \mathrm{e}-0 \\
(-1.1) \\
-1.1 \mathrm{e}-0 \\
\left(-3.1^{*}\right. \\
2.6 \mathrm{e}-0 \\
(0.0)\end{array}$ & $\begin{array}{l}7 \\
* \\
* \\
10 \\
0\end{array}$ & $\begin{array}{r}7.9 \mathrm{e}-00 \\
(1.5) \\
-7.1 \mathrm{e}-00 \\
(-1.2) \\
1.7 \mathrm{e}-00 \\
(3.9 * * * \\
2.0 \mathrm{e}-00 \\
(3.6 * * *\end{array}$ & & $\begin{array}{c}1.9 \\
\left(3.9^{* * *}\right) \\
1.7 \\
\left(2.4^{* *}\right) \\
0.6 \\
\left(1.7^{*}\right) \\
0.9 \\
\left(4.0^{* * *}\right)\end{array}$ \\
\hline $\begin{array}{l}\text { Germa } \\
\text { ny }\end{array}$ & \begin{tabular}{|c|}
$(73: 02-$ \\
$81: 02)$ \\
$(81: 03-$ \\
$87: 11)$ \\
$(87: 12-$ \\
$98: 12)$ \\
\end{tabular} & $\begin{array}{c}0.02 \\
(1.2) \\
0.05 \\
\left(4.6^{* * *}\right) \\
0.003 \\
(0.4)\end{array}$ & \begin{tabular}{|c|}
-9.0 \\
$(-1.4)$ \\
-19.0 \\
$\left(-5.4^{* * *}\right)$ \\
-1.1 \\
$(-0.5)$
\end{tabular} & & $\begin{array}{l}.7 e-005 \\
(-1.6) \\
.2 e-004 \\
\left.5.3^{* * *}\right) \\
0 e-005 \\
(0.4)\end{array}$ & $\begin{array}{r}2.0 \mathrm{e} \\
(0 \\
-6.5 \mathrm{e} \\
(-2.6 \\
7.8 \mathrm{e} \\
(1 .\end{array}$ & $\begin{array}{l}2-007 \\
.5) \\
e-007 \\
5 * * *) \\
-009 \\
.0)\end{array}$ & $\begin{array}{r}-2.9 \mathrm{e}- \\
(-0 . \\
-8.5 \mathrm{e}- \\
(-1 . \\
7.5 \mathrm{e}- \\
(0.8\end{array}$ & $\begin{array}{l}2-006 \\
.1) \\
2-005 \\
.4) \\
-006 \\
8)\end{array}$ & $\begin{array}{r}1.0 \mathrm{e}-0 \\
(0.7) \\
-4.4 \mathrm{e}-0 \\
(-0.9) \\
8.0 \mathrm{e}-0 \\
(0.7)\end{array}$ & & $\begin{array}{r}1.0 \mathrm{e}-00 \\
(0.8) \\
-1.5 \mathrm{e}-00 \\
(-0.6) \\
5.2 \mathrm{e}-00 \\
(0.9)\end{array}$ & & $\begin{array}{c}0.9 \\
\left(2.1^{* *}\right) \\
1.3 \\
\left(1.7^{*}\right) \\
0.9 \\
(3.9 * * *)\end{array}$ \\
\hline
\end{tabular}


Table 7 (cont.): Comparing integrated market model with segmented market model

\begin{tabular}{|c|c|c|c|c|c|c|c|c|c|}
\hline Country & Periods & Constant & $\operatorname{VAR}\left(\mathrm{R}_{\mathrm{i}}\right)$ & $\operatorname{COV}\left(R_{i}, 1 / I_{i}\right)$ & $\operatorname{cov}^{2}\left(R_{i}, 1 / l_{i}\right)$ & $\operatorname{cov}\left(\mathrm{R}_{\mathrm{i}}, 1 / \mathrm{I}_{\mathrm{i}}{ }_{\mathrm{i}}\right)$ & $\operatorname{COV}^{2}\left(R_{i}, 1 / I_{i}{ }_{i}\right.$ & $\begin{array}{c}{\left[\operatorname{COV}\left(\mathrm{R}_{\mathrm{i}}, 1 / \mathrm{I}_{\mathrm{i}}\right)^{*}\right.} \\
\operatorname{Cov}\left(\mathrm{R}_{\mathrm{i}}, 1 / \mathrm{I}_{\mathrm{i}}{ }^{*}\right]\end{array}$ & $\begin{array}{c}\text { Estimate } \\
\text { d Y }\end{array}$ \\
\hline \multirow{8}{*}{ Italy } & (73:02- & -1.0 & 62.0 & $-8.3 e-004$ & $-2.0 e-007$ & $-4.2 e-003$ & $-6.6 e-006$ & $-2.2 e-006$ & 0.9 \\
\hline & $81: 11)$ & $(-1.6)$ & (0.6) & $(-3.0 * * *)$ & $(-2.9 * * *)$ & $(-2.9 * * *)$ & $(-2.9 * * *)$ & $\left(-2.8^{* * *}\right)$ & (0.6) \\
\hline & (81:12- & 1.1 & -188.4 & $-1.4 e-005$ & $-2.6 e-008$ & $4.9 e-004$ & $5.0 e-007$ & $2.7 e-007$ & 2.3 \\
\hline & $86: 06)$ & $(3.7 * * *)$ & $\left(-5.6^{* * *}\right)$ & $(-0.2)$ & $(-2.9 * * *)$ & $(0.4)$ & $(0.4)$ & (1.1) & $\left(2.8^{* * *}\right)$ \\
\hline & (86:07- & 0.08 & -13.1 & $4.8 \mathrm{e}-005$ & $3.1 \mathrm{e}-008$ & $2.0 e-005$ & $-6.4 e-009$ & $2.5 e-007$ & 0.7 \\
\hline & 91:06) & $(0.4)$ & $(-0.4)$ & $(5.6 * * *)$ & $\left(5.7^{* * *}\right)$ & $(0.6)$ & $\left(-3.8^{* * *}\right)$ & $\left(7.4^{* * *}\right)$ & $\left(2.5^{* *}\right)$ \\
\hline & (91:07- & -6.3 & 980.0 & $-2.0 e-004$ & $-1.6 e-008$ & $-4.4 e-003$ & $-6.9 e-006$ & $-7.9 e-007$ & 1.1 \\
\hline & $98: 12)$ & $(-1.5)$ & (1.5) & $(-0.6)$ & $(-0.2)$ & $(-1.4)$ & $(-1.4)$ & $(-0.8)$ & $\left(3.3^{* * *}\right)$ \\
\hline \multirow{8}{*}{ Japan } & (73:02- & 0.01 & 0.4 & $1.8 \mathrm{e}-005$ & $4.3 \epsilon$ & -1.9 & $1.9 e-009$ & $9.8 e-009$ & 3.2 \\
\hline & 79:08) & $(-1.3)$ & $(1.2)$ & (0.7) & $\left(3.3^{* * *}\right)$ & $(-0$ & $(1.5)$ & (0.5) & $\left(3.2^{* * *}\right)$ \\
\hline & (79:08- & 9.0e-003 & -0.4 & $9.1 \mathrm{e}-006$ & $-3.9 e-010$ & $4.3 e-$ & $-2.4 e-011$ & $-3.5 e-010$ & 0.2 \\
\hline & $86: 03)$ & $\left(1.9^{*}\right)$ & $(-0.4)$ & $\left(4.5^{* * *}\right)$ & $(-0.3)$ & $\left(2.7^{* * *}\right)$ & $(-0.7)$ & $(-0.7)$ & (0.5) \\
\hline & (86:04- & -0.03 & -3.0 & $-1.0 e-004$ & $7.4 \mathrm{e}-008$ & $-1.8 e-005$ & $9.1 \mathrm{e}-009$ & $7.6 e-008$ & 2.5 \\
\hline & 90:01) & $(-1.1)$ & $(-0.8)$ & $(-5.0 * * *)$ & $(4.6 * * *)$ & $(-1.2)$ & $\left(3.5^{* * *}\right)$ & $\left(4.5^{* * *}\right)$ & $\left(4.6^{* * *}\right)$ \\
\hline & (90:02- & $1.8 \mathrm{e}-003$ & 0.3 & $-1.8 e-005$ & $6.5 e-010$ & $-4.0 e-007$ & $5.5 e-011$ & $1.5 e-009$ & 1.3 \\
\hline & $98: 12)$ & $(0.1)$ & (0.3) & $\left(-1.7^{*}\right)$ & $(0.8)$ & & (1.4) & $\left(1.8^{*}\right)$ & $\left(2.4^{* *}\right)$ \\
\hline \multirow{8}{*}{ UK } & (73:02- & -712.9 & 8.0 & 0.71 & -0.0009 & 2.2 & -0.002 & -0.002 & 0.98 \\
\hline & 75:09) & $(-1.6)$ & $\left(4.8^{* * *}\right)$ & $\left(2.7^{* * *}\right)$ & $\left(-2.1^{* *}\right)$ & $\left(1.8^{*}\right)$ & $(-2.0 * *)$ & $\left(-2.5^{* *}\right)$ & (1.5) \\
\hline & (75:10- & -58.3 & 0.1 & -0.21 & -0.0002 & 0.03 & -0.000001 & 0.00007 & 0.97 \\
\hline & $87: 11)$ & $(-0.8)$ & (0.1) & $(-0.8)$ & $(-0.7)$ & (1.0) & $(-0.9)$ & $(0.9)$ & $\left(3.2^{* * *}\right)$ \\
\hline & (87:12- & 2303.9 & -1.0 & 10.8 & 0.01 & 0.2 & -0.0002 & -0.0004 & 1.1 \\
\hline & $92: 11)$ & $(-1.1)$ & $(-0.7)$ & (1.4) & $\left(2.2^{* *}\right)$ & (0.1) & $(-0.7)$ & $(-0.1)$ & $\left(2.8^{* * *}\right)$ \\
\hline & (92:12- & 849.3 & -1.4 & 3.1 & 0.002 & -0.4 & -0.0002 & -0.002 & 0.97 \\
\hline & $98: 12)$ & $\left(1.6^{*}\right)$ & $(-0.3)$ & $\left(1.9^{*}\right)$ & $\left(2.0^{* *}\right)$ & $(-0.9)$ & $\left(-3.5^{* * *}\right)$ & $\left(-1.8^{*}\right)$ & $\left(10.2^{* * *}\right)$ \\
\hline \multirow{8}{*}{$\begin{array}{l}\text { Switzerl } \\
\text { and }\end{array}$} & (73:02- & $-8.9 e-004$ & 0.6 & $3.0 e-006$ & $-8.8 e-010$ & $-1.3 e-007$ & $1.1 \mathrm{e}-012$ & $-2.4 e-009$ & 1.1 \\
\hline & $83: 09)$ & $(-0.1)$ & $(0.2)$ & $\left(3.2^{* *}\right)$ & $\left(-8.2^{* * *}\right)$ & $\left(-8.3^{* * *}\right)$ & $(0.0)$ & $\left(-8.2^{* * *}\right)$ & $\left(2.4^{* *}\right)$ \\
\hline & (83:10- & -0.04 & 20.6 & $6.6 e-006$ & $6.1 \mathrm{e}-011$ & $-7.2 e-008$ & $-8.6 e-014$ & $-3.2 e-013$ & -0.1 \\
\hline & $87: 07)$ & $(-1.3)$ & $\left(1.7^{*}\right)$ & $\left(2.3^{* *}\right)$ & $\left(4.5^{* * *}\right)$ & $(-0.8)$ & $(0.0)$ & $(0.0)$ & $(-0.3)$ \\
\hline & (87:08- & 0.05 & -11.7 & $-7.7 e-007$ & $-3.3 e-011$ & $1.3 e-006$ & $4.6 e-012$ & $2.0 e-010$ & 0.0 \\
\hline & 91:05) & $\left(3.8^{* * *}\right)$ & $\left(-4.3^{* * *}\right)$ & $(-0.1)$ & $(-0.1)$ & $\left(1.9^{*}\right)$ & $\left(2.1^{* *}\right)$ & $(1.6)$ & (0.1) \\
\hline & (91:06- & 0.002 & -0.3 & $-1.8 e-007$ & $1.9 e-010$ & $-1.1 e-008$ & $-2.2 e-013$ & $5.0 e-010$ & 0.98 \\
\hline & $98: 12)$ & $(0.2)$ & $(-0.2)$ & $(-0.2)$ & $(0.8)$ & $(-0.8)$ & $(0.0)$ & $(0.8)$ & $\left(2.8^{* * *}\right)$ \\
\hline
\end{tabular}

Statistical significance at the $10 \%, 5 \%$, and $1 \%$ level is indicated by $*, * *, * * *$ respectively, $\mathrm{t}$ values are in parentheses

Second part (II) of the same table reports the regression results when the estimated value of national equity return by integrated market model is added as a regressor to the segmented market model. The segmented model is consistently significant over and behind integrated market model for all cases but one (both in full period and sub-period samples). On the other hand, integrated market model is significant in 3 out of 7 cases in full period sample and 20 out of 27 cases in subperiod samples over and behind segmented market model. Thus, it can be easily claimed that segmented model is a better choice for the periods analyzed. However, one can also claim that both models have some explanatory power over each other, thus the model that we could not analyze here, mildly segmented model, and could be the better choice. Indeed, when the adjusted $\mathrm{R}^{2} \mathrm{~s}$ of four class 
of regressions - Integrated market model (I) regressions, segmented market model (II) regressions, regressions where the regressors are the ones from integrated market model plus estimated national equity return by segmented market model (III), regressions where the regressors are the ones from segmented market model plus the estimated national equity return by the integrated market model (IV) - are compared, it is found that III has the highest adjusted $R^{2} s$, closely followed by IV. Thus, it looks like among the models that are analyzed segmented model is the best one. However, it can be also claimed that a "mildly segmented market" model that would capture the main characteristics of both integrated and segmented models could be the better model to use. Unfortunately, it was not possible to derive a mildly segmented model explaining risk-return relations due to the complexity of the model.

To summarize, the results support that exchange rate risk is an important factor in determining the risk-return relations. Therefore, the results provide that classic CAPM would not be able to fully explain the dynamics of international expected returns. However, the results only weakly support either the integrated market model or segmented market model proposed by the present study here. Although the pattern of significance of the variables could be satisfactory to support the models, the restrictions predicted by the models are not achieved and the adjusted $\mathrm{R}^{2} \mathrm{~s}$ are not high enough to claim that either of the models can satisfactorily explain the international returns. Rather, the results imply that a "mildly segmented model" would be a better choice than an "integrated" or a "segmented" market model.

\section{Conclusions}

The main result of this study is that the exchange rate risk is priced besides the market risk in international asset pricing. This result is consistent with the previous studies by (Solnik Bruno \& Dumas, B.,1995) and (Santis \& Gerard, B., 1998). The main contribution of the present study to these previous studies is in terms of the specification of exchange rate risk. Both of these studies considered three sources of exchange risk premium; the Deutsche mark, the Japanese yen, and the British pound whose selection has been justified by the fact that these markets cover more than $80 \%$ of the world portfolio. As pointed out by the authors of mentioned studies, including only three sources of currency risk can introduce a potential bias in the estimation of the currency risk. On the other hand, the model used in the current study itself determines which currencies should be included in an empirical test, thus avoids this kind of bias. Along with the lines of the theory by Bayraktar (2000 and 2009), in the empirical tests of each country the real exchange risks of this particular country's leading trading partners have been included. Therefore, any biases that may occur due to random selection of currency risks have been avoided. Despite this specification (in some way limitation) of the currencies, the empirical results provide that exchange rate currency is an important factor in the pricing of the securities. 
However, the empirical evidence only weakly support any one of the models proposed in this study. It provides some support since the exchange rate risk is priced. But, it is only a weak support since exchange rate is not consistently priced, the restrictions predicted by the models are not achieved and the adjusted $\mathrm{R}^{2} \mathrm{~s}$ are not high enough to claim that either of the models can satisfactorily explain the international returns. Moreover, the significance of the variables depends on the samples used. There could be different explanations for these results. First, it is possible that GARCH model specification of the time varying risks may not be really capturing the time series properties of the risks, thus, of the returns. Second, the structural break approach may not be rich enough to characterize the time-varying properties of the risk premia. Thus, a model specification where both risks and risk premia are time-varying may be needed. Third, the selected countries may not be the ones that are strongly affected by the exchange rate market changes. Maybe developing countries are more prone to the fluctuations in currency market thus a study that examines the very same model for developing countries would end up with more significant results. Finally, the results (especially the J-tests) could be really showing that neither the integrated model nor the segmented market model, independently, is a sufficient model to fully explain the risk-return relations. Rather, a "mildly segmented market model" which would lie in between complete segmentation and integration could be a better alternative to be used as an international asset pricing model.

\section{Acknowledgements:}

Special thanks should be given to Dr. Thomas C. Chiang, my supervisor for his professional guidance, valuable support and constructive recommendations on this paper.

\section{References}

Adler, M., \& Dumas, B. (June 1983). International Portfolio Choice and Corporation Finance: A Synthesis. Journal of Finance 38, 3, 925-984. http://dx.doi.org/10.1111/j.15406261.1983.tb02511.x

Ashley, A., \& R.\&M.Patterson D. (2010). "A Test of the $\operatorname{GARCH}(1,1)$ Specification for the Daily Stock Returns",. Macroeconomic Dynamics, Volume14-SupplementS1, 137-144. http://dx.doi.org/10.1017/\$1365100510000015

Bayraktar, S. (2000). International asset Pricing and Exchange rate Eisk: Theoretical Exposition, numerical analysis, and empirical investigation under integrated and frictional capital markets. Philadelphia: Drexel University.

Bayraktar, S. (2009). The impact of exchange rate risk on international assetpricing under various market structures. Review of Quantitative Finance and Accounting, 32(2), 169-195. http://dx.doi.org/10.1007/s11156-008-0089-4

Bekaert, G., \& Harvey,C. (1995). Time-varying world market integration. Journal of Finance, 50, 403-444. http://dx.doi.org/10.1111/j.1540-6261.1995.tb04790.x 
Bollerslev, T. (1990). Modelling the coherence in short-run nominal exchange rates: A multivariate generalized ARCH model. Review of Economics and Statistics, 72, 498-505. http://dx.doi.org/10.2307/2109358

Bollerslev, T., \& M.Wooldridge,J. (1992). Quasi-maximum likelihood estimation and inference in dynamic models with time-varying covariances. Econometric reviews, 11, 143172. http://dx.doi.org/10.1080/07474939208800229

Bollerslev, T., Engle, R.F., \& Wooldridge, J.M. (1988). A Capital Asset Pricing Model with Time-Varying Covariances. Journal of Political Economy, 96, $116-131$ http://dx.doi.org/10.1086/261527

Brown, R. L., Durbin, J., \& Evans, J.M. (1975). Techniques for testing the constancy of regression relationship over time. Journal of Royal Statistical Society, Series B, 149-163.

Cappiello, L., Castrén , O., \& Jääskelä, J. (2003). Measuring the Euro Exchange Rate Risk Premium: the Conditional International CAPM Approach. EFMA 2003, Helsinki, Finland, 1-30.

Chan, K., Karolyi, G.A., \& Stulz, R.M. (1992). Global Financial Markets and the risk premium in U:S. equity",. Journal of Financial Economics, 32, 137-167.

http://dx.doi.org/10.1016/0304-405X(92)90016-Q

Chang, J.-r., Errunza, V., Hogan, K., \& Hung, M.-w. (2005). An Intertemporal International Asset Pricing Model: Theory and Empirical Evidence. European Financial Management, 11(2), 173-194.

http://dx.doi.org/10.1111/j.1354-7798.2005.00281.x

Chelley-Steeley, P., Pentecost, E.J., \& Steeley, J. (1998). Exchange controls and European stock market integration. Applied Economics, 30, 263-267. http://dx.doi.org/10.1080/000368498326056

Davidson, R., \& Mackinnon, J. (1981). Several tests for model specification in the presence of alternative hypotheses",. Econometrica, 49, 781-793.

http://dx.doi.org/10.2307/1911522

Eugene, F. F., \& Andre,F. . (September 1979). Money, Bonds, and Foreign Exchange,. American Economic Review, 69(4), 639-649.

Garuer Frederick,L.A., Litzenberger Robert H. , \& Stehle Richard E. . (1976). Sharing Rules and Equilibrium in an International Capital Market Under Uncertainty,. Journal of Financial Economics, 3, 233-256.

http://dx.doi.org/10.1016/0304-405X(76)90005-2

Hamao, Y., Masulis, R.W. , \& Ng., V. (1990). Correlations in Price Changes and Volatility across International Stock Markets,. The Review of Financial Studies, 3(2), 281-307. http://dx.doi.org/10.1093/rfs/3.2.281

Hansen, P., \& Lunde A. (2005). A forecast comparison of volatility models: does anything beat a GARCH(1,1)?",. Journal of Applied Econometrics, 20(7), 873-889. http://dx.doi.org/10.1002/jae.800

Harvey, A. (1990). The Econometric Analysis of Time Series (2nd ed.). Cambridge, Mass.: MIT Press.

Harvey, C. (1991). The world price of covariance risk. Journal of Finance, 46, 111-157. http://dx.doi.org/10.1111/j.1540-6261.1991.tb03747.x

Heckerman Donald, G. (1972). On the effects of exchange risk. Journal of International Economics, 3, 379-387. 
http://dx.doi.org/10.1016/0022-1996(73)90029-9

Hsing, Y. (2011). Macroeconomic Determinants of the Stock Market Index and Policy Implications: The Case of a Central European Country. Eurasian Journal of Business and Economics, 4 (7), 1-11.

Johnston, J. (1984). Econometric Methods. New York: McGraw-Hill.

Korajczyk, R., \& Viallet, C. (1989). An empirical investigation of international asset pricing. Review of Financial Studies, 2, 553-585.

http://dx.doi.org/10.1093/rfs/2.4.553

Naik, P. K., \& Padhi, P. (2012). The Impact of Macroeconomic Fundamentals on Stock Prices Revisited: Evidence from Indian Data. Eurasian Journal of Business and Economics, 5(10), 2544.

Newey, W.K., \& Kenneth,D.W. (1987). A simple, positive semi-definite, heteroskedasticity and autocorrelation consistent covariance matrix. Econometrica, 55, 703-708. http://dx.doi.org/10.2307/1913610

Pagan, A. (Feb.1984). Econometric Issues in the Analysis of Regressions with Generated Regressors. International Economic Review, 25(1), 221-247. http://dx.doi.org/10.2307/2648877

Quandt, R. (1958). The estimation of the parameters of a linear regression system obeying two separate regimes. Journal of American Statistical Association, 53, 873-880. http://dx.doi.org/10.1080/01621459.1958.10501484

Quandt, R. (1960). Tests of the hypothesis that a linear regression system obeys two separate regimes. Journal of American Statistical Association, 55, 324-330. http://dx.doi.org/10.1080/01621459.1960.10482067

Santis, G. D., \& Gerard, B. (1998). How big is the premium for currency risk? Journal of Financial Economics, 49, 375-412.

Solnik Bruno, H. (1974a). The International pricing of risk: An empirical investigation of the world capital market structure. Journal of Finance, 29, 365-378. http://dx.doi.org/10.1111/j.1540-6261.1974.tb03051.x

Solnik Bruno, H., \& Dumas, B. (June 1995). The world price of foreign exchange risk. Journal of Finance, 50(2), 445-479.

http://dx.doi.org/10.1111/j.1540-6261.1995.tb04791.x

Solnik, H. B. (1973). European Capital Markets: Towards a General Theory of International Investment. Lexington, MA: Lexington Books.

Stehle, R. (1977). An empirical test of the alternative hypotheses of national and international pricing of risky assets. Journal of Finance, 32(2), 493-502. http://dx.doi.org/10.1111/j.1540-6261.1977.tb03287.x 